\title{
Da arte de conhecer as doenças: \\ o Diagnóstico da Economia Mineira de 1968 \\ e o planejamento do desenvolvimento de Minas Gerais
}

O Diagnóstico da Economia Mineira está feito. Espera-se, agora, a receita para a cura dos males (O Diário de Minas, 5/1/1969, p. 5).

\section{Resumo}

O tema do desenvolvimento regional politicamente orientado ocupa lugar de destaque na História Econômica de Minas Gerais. Desde o início do século $\mathrm{XX}$, e no transcurso das mais importantes etapas da transformação do sistema econômico brasileiro, a superação do subdesenvolvimento e da posição periférica do estado constituiu-se em prioridade para as elites mineiras. Entende-se que é imperativo o estudo do Diagnóstico da Economia Mineira, publicado no ano de 1968, se o objetivo é compreender as vicissitudes da evolução econômica do estado. Com este escrito pretende-se ressaltar o significado deste opulento documento, mormente as longevas filiações institucionais e matrizes teóricas que lhe forneceram legitimidade e o fez consentâneo com o seu tempo. O texto se estrutura em três partes: i) descrição e análise do documento; ii) breve histórico sobre o desenvolvimentismo em Minas; iii) apresentação de quatro estudos acerca de temas do Diagnóstico: transportes, energia elétrica, indústria açucareira e siderurgia
Marcelo Magalhães Godoy Professor e pesquisador do Cedeplar/Face/UFMG

Daniel Henrique Diniz Barbosa Professor do Instituto Federal de Minas Gerais e doutorando em História Econômica da USP

Lidiany Silva Barbosa

Doutoranda em História Social da UFRJ

\section{Key words}

Minas Gerais, Economic History, development, planning, BDMG.

JEL Classification N26, N46, N96.

\section{Palauras-chave \\ Minas Gerais, História \\ Econômica, desenvolvimento,} Classificação JEL N26, N46, N96.

\section{Abstract}

The issue of politically oriented regional development occupies an important place in the Economic History of Minas Gerais. Since the start of the 20th century, and throughout the most important transformative stages of the Brazilian economic system, overcoming underdevelopment and the peripheral position of the state has been a priority for the elites of Minas. We understand that it is essential to study the Diagnosis of the Economy of Minas, published in 1968, if the goal is to understand the vicissitudes of the state's economic development. This study emphasizes the meaning of this rich document, especially the long-lived institutional relationships and theoretical matrixes that lent it legitimacy and made it suited it to its time. The text is structured in three parts: i) description and analysis of the document; ii) brief background of developmentism in Minas; iii) presentation of four studies about the themes of the Diagnosis: transportation, electric energy, sugar industry and steel making. 


\section{1_Do Diagnóstico}

A palavra diagnóstico, como averbou Raphael Bluteau, no início do século XVIII, "é palaura de médico" (Bluteau, 1713, v. III, p. 219). Vocábulo de origem grega, que, embora tenha longo uso através dos séculos, manteve a significação sintetizada pela frase do pioneiro lexicógrafo de origem inglesa. Exemplos da constância da exclusiva acepção podem ser recolhidos em importantes dicionários dos séculos XVIII, XIX e XX, os quais, invariavelmente, confirmaram que diagnóstico é termo da Medicina.

Assim, consulta aos dicionários elaborados por Antônio de Moraes Silva (1831, tomo I, p. 606), Francisco Solano Constâncio (1854, p. 413), Domingos Vieira (1871, v. II, p. 1009), Francisco Júlio Caldas Aulete (1925, v. I, p. 724), Antônio Cândido Figueiredo (1936, v. I, p. 799), Laudelino Oliveira Freire (1940, v. II, p. 1932), Aurélio Buarque de Holanda Ferreira (1986, p. 584) e Antônio Houaiss (2001, p. 1030) revela a continuidade no significado da palavra. $\mathrm{Na}$ Enciclopédia Portuguesa Ilustrada, de Maximiano Lemos, o verbete Diagnostico explica que se trata de

termo essencialmente médico, exprime a arte de conhecer as doenças pelos seus symptomas ou a parte dos estudos medicos que se occupa da diagnose (conhecimento das doenças pelos seus symptomas) (Lemos, 1899-1908?, v. III, p. 775).

Não há, portanto, em nenhum desses compêndios, acepção que não ligue a palavra a ato médico específico.

Nessa medida, acredita-se não se tratar de gesto ocasional, ou mesmo sem consequência, titular e identificar com termo médico um estudo inaugural e de grande envergadura, realizado por agência pública voltada para a promoção do desenvolvimento regional. Considera-se improvável que não houvesse intenção em sobrelevar, por meio de metáfora, as disfunções de uma economia regional que se acreditava subdesenvolvida. Afirma-se que o emprego do vocábulo no título do documento representou certo pioneirismo semântico, se comparado com os congêneres anteriores, elaborados em Minas, desde o início do século XX, e que, guardadas as especificidades históricas, se revestiam de intenções semelhantes.

Como se buscará acentuar, a instituição (Banco de Desenvolvimento de Minas Gerais - BDMG) e seus integrantes principais (engenheiros e economistas) se apresentaram como reserva de autoridade técnica avançada quando urgia 
o enfrentamento de desafios econômicos transcendentes para o destino do estado. Identificar esses desafios e, principalmente, definir intervenção apropriada não se poderia realizar sem o concurso de instrumental competente. O resultado de estudo elaborado debaixo dessas premissas não comportaria melhor designação que a de termo esotérico, no sentido de restrito à competência do especialista. Tanto mais adequada a denominação, se empréstimo de campo profissional em que se objetiva a restituição da higidez àqueles que se encontram em desequilíbrio, ou doentes. Ademais, como se argumenta a seguir, o resultado geral do Diagnóstico ou a demonstração da condição de subdesenvolvimento de Minas, que articula os resultados parciais das muitas monografias que o compõem, salienta o caráter instrumental do documento, suporte para intervenção planejada e politicamente orientada. ${ }^{1} \mathrm{O}$ diagnóstico que se buscou ressaltar enfática e repetidamente não poderia prescindir de intervenção a esta-

\footnotetext{
A metáfora médica fica ainda mais evidente ao se considerar depoimento de Juarez Távora Veado, concedido a projeto de memória do Cetec, em que atribuiu a Fernando Reis, um dos principais autores do Diagnóstico, a expressão:
}

\author{
"Pior do que o diagnóstico é o \\ prognóstico" (Pereira e Le Ven, \\ 2002, p. 48). Da mesma forma \\ que o termo diagnóstico, \\ o vocábulo prognóstico é \\ termo exclusivamente médico, \\ conquanto de utilização muito \\ mais restrita.
}

belecer ou restituir o equilíbrio da economia mineira, portanto decorrência natural se considerada a premissa epistemológica indissociável da disciplina em que se buscou, por empréstimo, o termo. O título de propaganda do governo de Minas Gerais na revista $O$ Cruzeiro, de 13 de janeiro de 1970, aproximadamente um ano após o lançamento do Diagnóstico da Economia Mineira, não deixa dúvida quanto à articulação ressaltada: Depois do 'diagnóstico' o remédio: estamos trabalhando (ver imagem em Anexo).

No quadro da produção de estudos técnicos orientados para fins políticos, o Diagnóstico da Economia Mineira deve ser considerado enquanto marco por quatro razões principais:

i. por sua abrangência e profundidade temática e espacial, já que se trata de volumoso conjunto de estudos sobre a formação econômica e social de Minas Gerais;

ii. por ser o primeiro grande documento do BDMG que, no ano de 1968, contava com apenas seis anos de criação e atuação;

iii. pelo número e pelo perfil dos técnicos que se dedicaram a sua produção, inclusive pela importância do documento como fator de 
fortalecimento do poder da tecnocracia mineira ${ }^{2}$, em detrimento da elite política (Diniz, 1981);

iv. pela grande repercussão que obteve após sua publicação, uma vez que reforçou concepção de empobrecimento relativo de Minas e de sua exploração por outras unidades da Federação (Diniz, 1981).

Somam-se, portanto, razões políticas, econômicas e sociais a justificar a importância do documento. Assim, se comparado com as realizações anteriores, é válida a afirmação apresentada por seus autores, de que o Diagnóstico seria

sem dúvida, a mais extensa documentação jamais reunida acerca das condições econô- micas e sociais do estado. Representam sobretudo um esforco de apreensão e interpretação da realidade que se justifica, primeiro por ser inédito e, segundo, por ser global (Diagnóstico, 1968, v. I, p. 14).

Nesse sentido, observação panorâmica das preocupações que permearam o documento pode ser apreendida com base nos temas selecionados para estudo, ao longo dos seis volumes, como demonstra o Quadro 1.

A iniciativa da realização do Diagnóstico é creditada ao economista Fernando Antônio Roquete Reis, da Faculdade de Ciências Econômicas, e que, à época, era diretor do Departamento de Estudos e Planejamento (DEP) do Banco ${ }^{3}$.

\begin{tabular}{|c|c|c|c|}
\hline Neste texto, o termo & 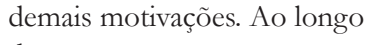 & Pte & $\mathrm{O}$ \\
\hline "tecnocracia" é utilizado para & do texto, entretanto, tenta- & zação & Nacional de Desenvolvimento \\
\hline designar o corpo técnico & se $\mathrm{r}$ & tros & \\
\hline integrado ao poder público & a "tec & ito & Dias e \\
\hline regional. Embora o termo & longe & & utura orgânica e \\
\hline possa remeter, conceitualmente, & $\mathrm{s}$ políticos e & ${ }^{3} \mathrm{~A}$ & E, até no que dir \\
\hline a ideia de autonomia irrestrita & soci & organizacional do B & fundos colocados sob \\
\hline do agente tecnicamente & nas questões de & foi inspirada no BNDE e & sua administração, foi definida por \\
\hline orientado em relação às demais & dese & rmente foi odantox & met \\
\hline esferas de poder, em que a & trat & à realidade e às necessidades & \\
\hline supremacia técnica suplante & essas áreas, conquanto & & $d i$ \\
\hline qual & op & o do DEP. Fundado & en \\
\hline organização política e social, & fundan & & gente do governo \\
\hline acredita-se na sua pertinência, & dos & Banco & o financiamento do \\
\hline na medida em que representa & & Nacional de Des & \\
\hline $\begin{array}{l}\text { a intenção de predomínio de } \\
\text { motivações técnicas sobre as }\end{array}$ & $\begin{array}{l}\text { da formulação de Fisichela } \\
\text { (1992, p. 133-137), para quem, }\end{array}$ & $\begin{array}{l}\text { Econômico (BNI } \\
\text { nova nomenclatur }\end{array}$ & $\begin{array}{l}\text { brasileira" (Dias e Ferreira, } 200 \\
\text { p. 483-484). }\end{array}$ \\
\hline
\end{tabular}




\section{Quadro 1_ Índice dos volumes do Diagnóstico}

(continua)

Volume I

Diagnóstico

\begin{tabular}{|c|c|}
\hline Apresentação & 3 \\
\hline Razões, Histórico e Metodologia & 7 \\
\hline Introdução & 17 \\
\hline Um modelo analítico & 21 \\
\hline \multicolumn{2}{|l|}{ Formação Histórica } \\
\hline Evolução Econômica & 49 \\
\hline Evolução Social & 81 \\
\hline Comportamento dos Grandes Agregados & 105 \\
\hline Demografia & 143 \\
\hline \multicolumn{2}{|l|}{ Infra-estrutura } \\
\hline Transportes & 157 \\
\hline Energia & 161 \\
\hline Serviços Sociais Básicos & 167 \\
\hline \multicolumn{2}{|l|}{ Agropecuária } \\
\hline Agricultura & 169 \\
\hline Pecuária & 173 \\
\hline Indústria & 177 \\
\hline \multicolumn{2}{|l|}{ Setor Público/Serviços } \\
\hline Atuação do Setor Público & 185 \\
\hline Comércio e Bancos & 197 \\
\hline \multicolumn{2}{|l|}{ Tomo I: Textos } \\
\hline \multicolumn{2}{|l|}{ Tomo II: Anexo cartográfico } \\
\hline Caracterização do espaço natural & 3 \\
\hline Geologia & 15 \\
\hline Relevo & 69 \\
\hline Hidrografia & 111 \\
\hline Condições Climáticas & 149 \\
\hline Pedologia & 169 \\
\hline Fitogeografia & 189 \\
\hline Regionalização & 207 \\
\hline Demografia & 3 \\
\hline Ensino & 59 \\
\hline Saúde e Assistência & 77 \\
\hline Transportes & 89 \\
\hline
\end{tabular}


Quadro 1_ Índice dos volumes do Diagnóstico

\begin{tabular}{|c|c|c|}
\hline & & (conclusão) \\
\hline & Energia Elétrica & 149 \\
\hline & Abastecimento de água e rede de esgotos & 203 \\
\hline \multirow{5}{*}{$\begin{array}{l}\text { Volume IV } \\
\text { Agropecuária }\end{array}$} & Situação agrícola de Minas Gerais & 3 \\
\hline & Produção agrícola & 29 \\
\hline & Distribuição fundiária & 89 \\
\hline & Mecanização & 115 \\
\hline & Pecuária & 119 \\
\hline \multirow{14}{*}{$\begin{array}{l}\text { Volume V } \\
\text { Indústria }\end{array}$} & Comportamento & 3 \\
\hline & Indústria extrativa mineral & 33 \\
\hline & $\begin{array}{l}\text { Transformação dos minerais não } \\
\text { metálicos }\end{array}$ & 67 \\
\hline & Metalurgia & \\
\hline & Metalurgia dos minerais ferrosos & 101 \\
\hline & Metalurgia dos metais não ferrosos & 148 \\
\hline & Indústria mecânica e de material elétrico & 171 \\
\hline & Indústria de madeira & 203 \\
\hline & Indústria têxtil & 217 \\
\hline & Calçados & 233 \\
\hline & A indústria alimentar & 249 \\
\hline & A indústria açucareira & 285 \\
\hline & A indústria de laticínios & 325 \\
\hline & A indústria do abate & 343 \\
\hline \multirow{8}{*}{$\begin{array}{l}\text { Volume VI } \\
\text { Serviços e Setor Público }\end{array}$} & Comércio & 3 \\
\hline & Setor bancário & 35 \\
\hline & Comunicações & 67 \\
\hline & Ótica financeira & 107 \\
\hline & CEMIG & 165 \\
\hline & CAMIG & 189 \\
\hline & CASEMG & 205 \\
\hline & FRIMISA & 219 \\
\hline
\end{tabular}

Fonte: Índices do Diagnóstico da Economia Mineira (1968). 
Outros dois economistas também coordenaram a realização dos estudos - Élcio Costa Couto e Álvaro Fortes Santiago. Finalmente, com o engenheiro José Vianna de Assis, se forma o conjunto de técnicos responsáveis pela idealização da produção do Diagnóstico. Os estudos foram realizados durante vinte meses $\mathrm{e}$ contaram com a participação de cerca de quarenta técnicos do BDMG e de outras instituições (Diagnóstico, 1968, v. I, p. 203).

Para a efetivação do Diagnóstico, o BDMG firmou convênio com a Comissão Interestadual da Bacia $\mathrm{Pa}$ raná-Uruguai (CIBPU), então dirigida por Antônio Delfim Neto. No Quadro 2, apresenta-se a lista dos autores do documento.

Como anunciado na sua apresentação, o conjunto de estudos reunidos sob a alcunha de Diagnóstico,

constitui a primeira análise sistematizada, de relativa profundidade, sobre o comportamento da economia mineira (Diagnóstico, 1968, v. I, p. 3).

A justificativa apresentada pelos autores para sua realização coincidia com a própria razão de ser do Banco. O objetivo é claro e apresentado na primeira página do volume I:
Procurou-se, como primeiro objetivo, conbecer a realidade sobre a qual operamos a fim de não continuarmos submetidos à contingência de termos de adotar diretrizes operacionais a partir de critérios inspirados pela intuição (Diagnóstico, 1968, v. I, p. 3).

O Banco, dadas as suas atribuições de órgão de promoção do desenvolvimento regional, necessitava conhecer de forma completa e sistematizada a realidade sobre a qual interviria. Os estudos deveriam, portanto, embasar e orientar a atuação do BDMG. Ainda, segundo os autores, o Banco enfrentava, na sua fase inicial, diversas dificuldades, entre as quais se destacava o conhecimento insuficiente da economia mineira.

Os objetivos do Diagnóstico transcendiam, entretanto, os anunciados em sua apresentação. Tratava-se, na realidade, de proposta ambiciosa, tanto do ponto de vista doutrinário como político, uma vez que refletia a

inquietação de um conjunto de pessoas imbuidas de uma ideologia 'desenvolvimentista', como forma de buscar caminhos para a superação do atraso econômico de Minas Gerais e de projetar a instituição na qual trabalhavam (Diniz, 1981, p. 156). 


\section{Quadro 2_Autores do Diagnóstico}

\begin{tabular}{|c|c|}
\hline Dos quadros do BDMG & $\begin{array}{l}\text { Abílio Santos, Álvaro Fortes Santiago, Angelina M. Rezende Dias, } \\
\text { Antônio Luiz Portugal Moura, Carlos Eduardo Côdo Aroeira, Clé- } \\
\text { lio Campolina Diniz, Dalmart Chaves Ivo, Eduardo Beluco Marra, } \\
\text { Élcio Costa Couto, Fernando Antônio Roquette Reis, Geraldo Se- } \\
\text { bastião Silva, Gelmar B. J. Costa, Henrique Oswaldo de Andrade, } \\
\text { João Ribeiro Filho, José Cummings Abubakir, Luiz Carlos Vieira } \\
\text { da Silva, Luciano Rogério de Castro, Marneu Ferreira Starling, Oto } \\
\text { Jacob, Ronald Castello Branco, Sérgio C. Miranda Lana, Teodoro } \\
\text { Alves Lamounier, Wilson Castello Branco }\end{array}$ \\
\hline Da CIBPU & Hilton Livieiro Pezzoni \\
\hline De outras entidades & $\begin{array}{l}\text { Carlos Alberto Macedo Rocha, David Márcio S. Rodrigues, Fer- } \\
\text { nando Correia Dias, Fabiano Marques dos Santos, Feliciano Cos- } \\
\text { ta Araújo, Getúlio Vargas Barbosa, José Armando de Souza, José } \\
\text { Murilo de Carvalho, José Birchal Wanderley, Paulo Roberto Haddad }\end{array}$ \\
\hline $\begin{array}{l}\text { Colaboradores dos quadros } \\
\text { do BDMG }\end{array}$ & $\begin{array}{l}\text { Álvaro Luiz da Motta Pelegrino, Chaquik Abdo Haddad, Flávio } \\
\text { Saliba Cunha, Hugo Mazzochi, Ivo Andrez Horta, Leon Menache, } \\
\text { Maria Augusta Roque da Silveira, Maria Malla Dutra Reis, Márcio } \\
\text { Augusto de Menezes, Marcus Eolo de Lamounier Bicalho, Mário } \\
\text { de Abreu Castello Branco, Ronaldo Barreto, Vilma Maria Tessele e } \\
\text { Zélia Maria de Moura Mello }\end{array}$ \\
\hline $\begin{array}{l}\text { Colaboradores não pertencentes } \\
\text { aos quadros do BDMG }\end{array}$ & $\begin{array}{l}\text { Antônio Afonso Carrara de Melo, Antônio Pereira Dias, Edmar } \\
\text { Rodrigues, Edson Medeiros, José Alberto Magno de Carvalho, Jo- } \\
\text { sé Mendonça de Almeida Filho, Maria do Carmo Ottoni, Magno } \\
\text { Pavlowsky, Manuel Arruda, Paulo Henrique Sampaio Vianna, Ro- } \\
\text { gério P. P. Mascarenhas, Walter Fuad Couri e Walter Lopes }\end{array}$ \\
\hline
\end{tabular}

Fonte: Diagnóstico da Economia Mineira (1968, v. I, p. 205).

Diversamente do que ocorreu nas décadas anteriores, a experiência do Diagnóstico representava uma iniciativa com a finalidade de planejamento a ser realizada por um órgão público criado especificamente para cumprir esse desígnio.
Ou seja, a partir de então, já não seria possível pensar o planejamento do desenvolvimento regional e prescindir do BDMG e de seus instrumentos. O Banco tomou para si a função de órgão de estudo do governo estadual, funcionan- 
do como nova instituição a reunir a tecnocracia mineira (Diniz, 1981). O lugar estava redefinido; colocava-se a questão da conquista de espaço político e social. Nessa medida, as questões resumidas nas perguntas abaixo, transcritas do primeiro volume do Diagnóstico, são exemplares da busca por demarcação de lugar dos estudos tecnicamente orientados no processo de construção de políticas de planejamento regional: eles deveriam precedê-las e embasá-las, sempre.

a) Como definir uma coerente politica de financiamento à indústria, sem conhecer a realidade deste setor ou de suas inter-relações com os demais setores da economia? b) De que modo alocar racionalmente os recursos, espacial on setorialmente, sem uma visão ampla da economia mineira? c) Como definir as necessidades de investimento sem se ter sequer uma idéia do volume de inversões anuais realizadas pelo Estado? d) De que maneira prever a capacidade de reação do setor privado sem se ter pelo menos uma avaliação de suas possibilidades para formar poupanças? e) Como dimensionar a capacidade de absorção de investimentos da economia sem o conbecimento de seus recursos naturais e humanos? f) De que maneira medir os efeitos multiplicador e acelerador das inversões realizadas sem conbecer a magnitude das componentes da renda e do produto? g) Como avaliar a sua própria capacidade para captar recursos senão através de um conhecimento mais perfeito das fontes financiadoras, especialmente o Estado? h) De que modo elaborar medidas coerentes sem um conhecimento sistemático do aparelho administrativo governamental e de seu funcionamento? i) E, finalmente, como definir o seu esquema de atuação sem o conbecimento preciso da forma como tradicionalmente atua o Governo em Minas? (Diagnóstico, 1968, v. I, p. 8-9)

Logo, é inquestionável a estreita ligação entre a feitura do Diagnóstico e as atribuições do Banco de Desenvolvimento de Minas Gerais. Sobretudo se considerado que um de seus efeitos práticos foi o fortalecimento do Banco junto aos governos estadual e federal (Diniz, 1981). A novidade representada pelo Diagnóstico, em relação às iniciativas anteriores, foi ressaltada pelos próprios autores que, mesmo reconhecendo a existência e a qualidade dos trabalhos precedentes, os tomaram

por insuficientemente informados, ou exclusivamente descritivos. Faltou, a todas as tentativas anteriores, um grau razoável de interpretação. Logo não se trata aqui de atualizar estudos anteriores (Diagnóstico, 1968, v. I, p. 9-10).

Reconheciam a tradição existente em Minas Gerais na produção de bons estudos técnicos, mas, por outro lado, de- 
marcavam que a iniciativa continha pontos importantes de descontinuidade e inovação. ${ }^{4}$

Alguns atributos distintivos do Diagnóstico merecem destaque. Em primeiro lugar, a análise não se limita aos anos coevos à sua elaboração; ao contrário, reúne, sempre de forma articulada, três dimensões temporais para a avaliação econômico-social de Minas Gerais: passado, presente e futuro. $\mathrm{O}$ segundo atributo é o uso sistemático do recurso da comparação da realidade mineira com outras experiências. ${ }^{5} \mathrm{E}$, em terceiro lugar, a realização de análise do próprio Estado, ou do "comportamento do setor público", na promoção do desenvolvimento regional. A presença de perspectiva histórica e comparativa, o uso de instrumentais da sociologia, além dos próprios à economia, conferem traço de originalidade ao Diagnóstico.

De forma geral o estudo não foge aos esquemas tradicionais de 'diagnóstico' realizados para efeito de planejamento. Procura, finalmente, caracterizar o território mineiro e avaliar seus recursos naturais através de estudos ligados à Geografia em geral e à Geologia, Climatologia, Fitogeografia, Hidrografia, Pedologia, em particular. Os recursos humanos são estudados em monografias específicas de demografia e educação, as quais buscam avaliar o estoque disponivel de mão-de-obra, bem como, suas qualificações e os condicionamentos sociológicos e econômicos de seu comportamento. Nos estudos setoriais foi dada especial ênfase à indústria e à agricultura, quando se tentou um tratamento de modo a permitir, a par da evolução histórica, uma visão de sua posição em face da economia mineira, do Brasil e de determinadas regiões. Por outro lado, os trabalhos abrangeram também o comércio, bancos, intermediários financeiros, comunicações, transportes, energia, saúde. Na análise do setor público, ao lado do tradicional enfoque sobre a receita e despesa, fez-se uma abordagem institucional, tentando identificar a estrutura e o comportamento básico do Poder Público em Minas Gerais (Diagnóstico, 1968, v. I, p. 11).

As principais conclusões do Diagnóstico estão apresentadas em dezenove itens no primeiro volume. Minas Gerais foi definido como um estado em situação de subdesenvolvimento, cujos principais indicadores eram: baixo grau de urbanização, predomínio das atividades agropecuárias, grandes diferenças de produtividade, níveis reduzidos de atendimento à saúde e de escolarização. $\mathrm{O}$ Diagnóstico reafirmava a concepção de secular exploração de Minas Gerais: primeiro na mineração, depois no fornecimento de minério e produtos primários

\footnotetext{
produção de estudos técnicos politicamente orientados, ver a segunda seção deste artigo.

5 Essa comparação era constante ao longo dos volumes do Diagnóstico. Seja quando os autores afirmavam que São Paulo e Guanabara (estado do Brasil de 1960 a 1975, no território do atual município do Rio de Janeiro) polarizavam o investimento industrial, seja quando receavam a concentração do investimento do governo federal na região atendida pela Sudene, ainda em fase de implantação na década de 1960, a posição de Minas apresentava-se fragilizada na comparação, uma vez disposta sempre na periferia do investimento privado ou público.
} 
para os polos industriais e, por fim, na exportação de insumos industrializados e de energia elétrica para a industrialização de São Paulo.

Muitas questões são suscitadas com base na apreciação do Diagnóstico, no contexto em que foi elaborado, de sua autoria, estrutura e objetivos. Algumas parecem evidentes e de fácil demonstração de relevância, como é determinar, por exemplo:

i. qual o padrão de relacionamento entre a elite técnica reunida em torno da formulação deste documento, e que se projeta valendose de seus resultados, e as elites políticas e empresariais?

ii. que relação prevalecia entre os autores e as suas instituições de formação e de exercício profissional?

iii. prepondera certa identidade teórica e metodológica a presidir os ensaios que compõem o Diagnóstico ou predomina a vigência de distintas posições doutrinárias a revelar conflito entre o pertencimento a grupo de trabalho e a formação técnica e inclinação ideológica de seus autores?

iv. conjunta ou individualmente, os ensaios do Diagnóstico podem ser considerados como interpretação ou interpretações originais da História Econômica de Minas Gerais?

No Brasil, as políticas públicas orientadas para o desenvolvimento regional sofreram forte inflexão entre o final do século XIX e o início da segunda metade da centúria seguinte. Especialmente a partir de 1930, as economias regionais foram arrastadas pelo processo de integração do mercado interno, que inviabilizou qualquer projeto de desenvolvimento autonomista. Progressivamente, conformou-se divisão regional do trabalho polarizada pela economia de São Paulo e que, direta ou indiretamente, tornou complementares e/ou subsidiárias às economias dos demais estados brasileiros. A ausência de planejamento central a presidir o processo de industrialização do País resultou no estabelecimento de pronunciados desequilíbrios regionais, setoriais e sociais (Cano, 1985). No princípio da década de 1960, estava consolidada a consciência dos graves problemas engendrados pelo modelo de industrialização por substituição de importações, que vigorou entre as décadas de 1930 e 1950 e que se esgotara no final do governo Juscelino Kubitschek (Tavares, 1973). Desse momento em dian- 
te, pensar e implementar políticas públicas de desenvolvimento regional, no âmbito dos governos estaduais ou a partir do governo federal, pressupunha enfrentar problemas antigos potencializados por novas dificuldades. Significava afrontar a herança de séculos de exploração colonial e de décadas de centralismo burocrático do período imperial, agravada por excessiva concentração econômica em São Paulo.

Além dessas irresistíveis e irreversíveis determinações, as políticas públicas voltadas para o desenvolvimento de Minas Gerais defrontaram-se com a grave crise econômica, política e social do início da década de 1960. Tratavase de crise de crescimento, limite a partir do qual ou se operariam importantes transformações na estrutura econômica e social, com a promoção de desenvolvimento econômico combinado com desenvolvimento social, ou se romperia a ordem institucional e se fortaleceria modelo de desenvolvimento conservador, no sentido de ser concentrador e excludente (Lessa, 1975). A solução autoritária do conflito político e social que polarizou a sociedade brasileira levou à gradual despolitização do debate em torno dos desequilíbrios regionais do $\mathrm{Pa}$ ís. Em outros termos, a proposição e a implementação de projetos com o objetivo de resolver ou reduzir problemas regionais seriam progressivamente esvaziadas de intenções que pressupusessem ou resultassem em alterar a estrutura econômica e social do Brasil. Restava buscar fórmulas sensíveis às referidas determinações próprias ao processo de modernização do País e, ao mesmo tempo, compatíveis com o bloco de poder hegemônico.

No quadro da centralização política autoritária do final da década de 1960 e da hegemonia de modelo econômico que estreitava sobremaneira a autonomia dos estados na definição dos rumos de suas políticas de desenvolvimento regional, parecia restar ao governo de Minas a adoção de estratégia que, a partir da mobilização da autoridade tecnocrática, sensibilizasse o governo federal para a decidida intervenção com vistas à superação de problemas graves e característicos da formação histórica mineira. A mensagem do então governador Israel Pinheiro ao presidente da República, na abertura de publicação que precedeu a divulgação do Diagnóstico, não deixa dúvida quanto à vigência da referida estratégia.

Excelentíssimo Senhor Presidente: Tenho a satisfação de entregar a Vossa Excelência a 'Sintese do Diagnóstico da Economia 
"Desenvolvimento, no terreno socioeconômico, é uma idéia referente à superação intencional de uma situação de atraso relativo. Envolve, portanto, uma clara dimensão política, que se traduz em ações governamentais - mediante graus variáveis de intervenção - $e$ também em articulações de classes e grupos diversos (sobretudo as elites politicas, econômicas e intelectuais) em torno da meta de superação do atraso. Podemos chamar de desenvolvimentismo ao pensamento que focaliza esse processo numa perspectiva de projeto, realçando seu sentido estratégico e seu potencial mobilizador" (Dulci, 2005, p. 114).
Mineira', documento elaborado para a sua consideração na oportunidade em que o Estado de Minas Gerais tem a honra de receber a presença do Govêrno Federal. Essa obra pretende afirmar-se como instrumento através do qual o Govêrno da União, conhecendo a realidade do Estado, possa decidir da validade das sugestões que se apresentam a Vossa Excelência. À medida que as sugestões sejam coerentes com as indicações que nasceram de estudo a tal nivel técnico, representarão providências que permitam a Minas Gerais vencer obstáculos e retomar o desenvolvimento. Estou convencido de que Vossa Excelência, ao examinar nossos problemas, convencer-se-á de que Minas Gerais, fiel aos seus destinos, há de vencer o atraso relativo em que se encontra, contando com a indispensável ação do Governo Federal. Animado por estas perspectivas, apresento a Vossa Excelência a sincera e respeitosa homenagem do povo mineiro. Com o apreço de Israel Pinheiro, Governador (Síntese do Diagnóstico, 1967)

Por tudo que se discutiu até aqui, conclui-se que a criação do BDMG e a elaboração do Diagnóstico da Economia Mineira não podem ser pensadas fora de enquadramento de longo prazo, portanto histórico, e que considere múltiplas determinações econômicas, políticas e sociais. Além disso, pensar tanto a instituição como o próprio documento por ela produzido, o Diagnóstico, impõe a observação de tradição regional que remonta, ao menos, ao princípio do período republicano mineiro. Se o Diagnóstico é uma ruptura no que concerne à prática do planejamento estatal em Minas, dada a excelência de sua pesquisa e a abrangência de suas preocupações, não deixa de ser, ao mesmo tempo, produto muito bem acabado que se inseria, no médio prazo, na lógica que, segundo Dulci (1999), foi lentamente sendo construída regionalmente: a perspectiva da recuperação econômica como uma tarefa ao mesmo tempo técnica e operada pelo Estado.

\section{2_Do desenvolvimentismo em Minas Gerais}

Os esforços no sentido de se mobilizar os interesses políticos e econômicos regionais, com o objetivo de superar o atraso relativo da economia mineira, podem ser percebidos já na organização do I Congresso Agrícola, Industrial e Comercial (I CAIC), realizado em 1903, em Belo Horizonte, sob a presidência de João Pinheiro. Ao fundar um suposto "desenvolvimentismo mineiro" (Dulci, 2005, p. 114), esse evento inaugurou agenda econômica para Minas, em que propostas de modernização da produção agrícola, de diversificação produtiva e de polí- 
tica mineral arrojada estavam associadas à perspectiva de apoio do poder público para se efetivar. Além disso, conferia relevância ao ensino técnico para o bom desempenho regional em projeto de desenvolvimento econômico (Dulci, 1999, p. 37-53).

Conquanto os elementos resultantes do I CAIC sejam importantes no que tange à precocidade com que certa noção de planejamento da economia regional se constituiu em Minas Gerais, o caráter da economia e do sistema político brasileiros vigentes na República Velha obliterou a plena efetivação da maioria de suas propostas. Muito embora sua agenda se mantivesse proeminente na definição da política econômica do estado nos anos seguintes, como sugere a realização do II Congresso em 1927 (Vieira, 1984), muitas propostas apresentadas no I CAIC não tinham ainda, em fins da década de 1920, encontrado implementação efetiva. Somente com as profundas transformações econômicas decorrentes da crise de 1929 e com a ruptura política representada pela Revolução de 1930 tornou-se imperativa a necessidade de reorientação da economia mineira, enfrentando-se de forma mais eficaz determinados problemas que, desde 1903, já estavam relativamente demarcados.
Ainda para a primeira metade da década de 1930, deve-se considerar uma série de desdobramentos políticos e econômicos tributários do colapso do sistema político da Primeira República e da crise econômica mundial. Em primeiro lugar, há que se ressaltar que o sistema de interventorias, definido originalmente por Getúlio Vargas, não alcançou Minas a princípio. Olegário Maciel mantevese presidente do estado, muito embora com sérias dificuldades em organizar uma resposta efetiva do poder público mineiro à crise instalada (Dulci, 1999). Com sua morte, em setembro de 1933, abriu-se espaço para que o governo federal nomeasse um interventor. Foi Benedito Valadares o escolhido por Vargas para a interventoria mineira. Nesse sentido, 1933 marca importante inflexão para Minas Gerais. Politicamente, por registrar a ascensão de político tangencial aos grupos tradicionais ao centro do poder público mineiro (Vieira, 1984). No que concerne à economia, por definir atuação estatal centralizada, especialmente na recuperação financeira e na definição de rumo para o desenvolvimento econômico de Minas.

Nesse sentido, torna-se relevante o papel desempenhado pela Secretaria de Agricultura, Indústria, Comércio, Tra- 
balho, Viação e Obras Públicas, que, comandada pelo engenheiro Israel Pinheiro, ficou responsável pela definição das políticas de fomento ao desenvolvimento econômico regional, bem como por congregar, na esfera pública, a categoria profissional do engenheiro, forjando o que Diniz (1981) considera como o "embrião da tecnocracia mineira". Em linhas gerais, a atuação da Secretaria pode ser compreendida, no período do governo Valadares (1933-45), em três fases distintas:

i. ênfase no setor agrícola entre 1933 e 1937;

\footnotetext{
Para Otávio S. Dulci (1999, p. 61), o governo Valadares se divide em duas fases:

i. entre 1933 e 1940 , período em que o governo estadual se concentrou na perspectiva de diversificação agrícola e; ii. 1941 a 1946, época em que a expansão industrial ganhou maior relevância. Propõe-se outra divisão por se considerar que: i. desde 1938 a agenda agrícola já havia sido suplantada pela agenda siderúrgica (Barbosa, 2005; Vieira, 1984); ii. o período de defesa de uma política de industrialização baseada na siderurgia foi essencial para o encaminhamento futuro do planejamento da
}

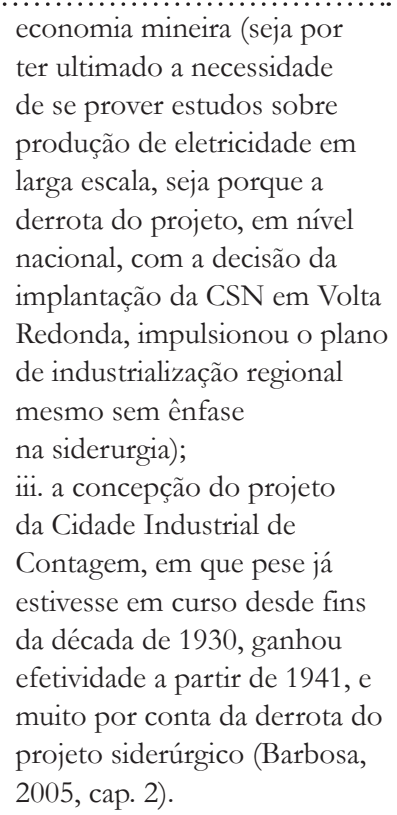

ii. valorização da industrialização por meio da grande siderurgia entre 1938 e 1941 ;

iii. aposta na Cidade Industrial de Contagem, a partir de 1941, como opção pela industrialização menos atrelada à grande siderurgia. ${ }^{?}$

Com o fim do Estado Novo, em 1945, concluiu-se também o período valadarista em Minas. Assim, o peso da perspectiva de expansão industrial, que marcara as estratégias do poder público regional desde 1940, será atenuado quando da eleição de Milton Campos ao governo do Estado, no pleito de 1946. Atenuado, conquanto não descartado. Antes, à perspectiva de expansão industrial aliou-se, em condição de igualdade, e de forma simultânea, projeto de diversificação e modernização agrícola, ambos propostos pelo Plano de Recuperação Econômica e Fomento da Produção, lançado em 1947 e formulado e coordenado pelo engenheiro Américo Renné Giannetti, secretário de Agricultura do governo Campos. O Plano constitui marco importante na medida em que representa esforço de planejamento integrativo (indústria e agropecuária), ao mesmo tempo em que cria a Taxa de Recuperação Econômica, tributo significativo para o 
desenvolvimento econômico regional nas décadas de 1950 e 1960 (Dias, 1969, p. 119). ${ }^{8}$

Também será no governo de Milton Campos que se concretizará outro documento relevante: o Plano de Eletrificação de Minas Gerais. Aparentemente, por se tratar de documento preciso na "avaliação da geografia econômica regional", com "dados e interpretações da expansão industrial" mineira (Dias, 1969, p. 117), pode ser articulado ao Plano de Recuperação. Além disso, foi importante fonte de dados para a constituição das Centrais Elétricas de Minas Gerais (Cemig), em 1952, primeira empresa de capital misto brasileira. Criada no governo de Juscelino Kubitschek, que assume em 1951, a Cemig revela o esforço pela priorização da especialização industrial em detrimento do setor agropecuário, sendo expressão importante, senão fundamental, daquilo que se consagrou como o Binômio Energia e Transportes (Dulci, 1999, p. 97).?

Além de sua relevância evidente no tocante à questão energética, a fundação da Cemig se mostra de grande interesse por se definir, desde o princípio, como um espaço voltado para o debate técnico, esvaziando, em certo sentido, essa característica da Secretaria de Agricultura. Embora pioneira, a Cemig não foi exclusiva; ainda na década de 1950, várias outras empresas públicas, mas de capital misto, foram fundadas em Minas Gerais. Essas empresas notabilizaram-se pelo alto perfil técnico, com ampla racionalidade administrativa, de forma divergente dos espaços tradicionais do poder público. Essa característica engendrou, a partir do princípio da década de 1960 , tentativa de reforma administrativa no poder público mineiro, sob a gestão do então governador José de Magalhães Pinto, definida tanto por plano de classificação de cargos como por redefinição das funções das secretarias de governo (Dias, 1969).

Será nesse governo que, em 1962, se fundará o BDMG. Diferentemente das demais empresas de capital misto, a instituição será criada como uma autarquia, a partir de regulamento baixado pelo Poder Executivo. O BDMG respondeu ao debate entabulado principalmente na esfera administrativa do poder público mineiro, como também pela elite técnica regional (por meio de suas associações de categoria profissional) e pelas entidades dos setores produtivos de Minas. Curiosamente, segundo Dias (1969,
Significativo, porém não unanimemente aceito pelo empresariado mineiro. De acordo com Delgado (1997), parcela importante desse grupo - especialmente o setor ligado à Fiemg, relutou muito em aceitar sua implantação. Em linhas gerais, o Plano Giannetti estipulava a criação da Taxa, com vigência a partir de 1948 , estendendo-se até 1952, com alíquota progressivamente menor a cada ano, quando, então, deveria estar cumprida a agenda de investimentos. A Taxa, na verdade, perdurou até a década de 1960 como importante mecanismo de financiamento do poder público mineiro.

9 Ver, sobre a Cemig, item 3.2. 
p. 130-31), a instituição não foi proposta pelo governo Magalhães Pinto, e sim por deputado oposicionista, que fez aprovar projeto de lei, na Assembleia Legislativa, criando mais uma sociedade de capital misto a ser gerida pelo Estado, responsável pelo fomento econômico, embora exclusivamente agropecuária.

Por meio de vetos governamentais, contudo, os assessores do Executivo conseguiram adaptar o projeto, tornando-o uma autarquia e, sobretudo, transformando-o de Banco de Desenvolvimento Agropecuário em Banco de Desenvolvimento. Para Dias (1969), o fato de ter se tornado um banco de fo- mento nos moldes do BNDE foi fundamental para sua rápida consolidação, fruto da gestão específica que lhe determinou o governo Magalhães Pinto. Deve-se ressaltar, no entanto, que o Banco passou por "um processo de adaptação demorado e paralisante" (Dias, 1969, p. 131) no início da gestão Israel Pinheiro, curiosamente o momento em que se gestou o Diagnóstico. ${ }^{10}$

A assinalada preocupação teórica da instituição, tanto com a questão do planejamento industrial, na perspectiva da CEPAL, como com a problemática do desenvolvimento de economias regionais, fomentou a organização do
De acordo com PereiraDiniz (2008), a ideia de criação de um banco destinado a dar suporte ao projeto emergente de industrialização de Minas Gerais remonta ao princípio da década de 1950, portanto antes da criação do BNDES. Com esse objetivo, o então governador Juscelino Kubitschek encaminhou à Assembleia Legislativa a Mensagem n. 65, de 26 de julho de 1951, propondo a criação do Banco de Investimento de Minas Gerais. Segundo o autor, em virtude de forte resistência do setor agrário representado na Assembleia Legislativa, o projeto foi arquivado. Seis anos após essa recusa, foi a vez de a Federação das Indústrias de Minas Gerais (Fiemg) renovar a tentativa. Assim, em 1957, o Departamento de Estudos Econômicos da Fiemg concluiu trabalho por meio da qual se tentou retomar a proposta de criação de instituição financeira de fomento ao desenvolvimento regional. Todavia, mais uma vez frustrou-se a tentativa em virtude da resistência do conservadorismo do setor agrário, fortalecido pela oposição de entidades que recebiam parcelas da Taxa de Recuperação Econômica. Dessa forma, foi somente em 1959 que os defensores do setor primário submeteram à Assembleia Legislativa novo projeto de lei que propunha a criação do Banco de Desenvolvimento Agropecuário de Minas Gerais (BADAP). Após muitos debates, com base no texto inicial e em transformações significativas conferidas por meio de vetos do governador Magalhães Pinto, com a Lei n. 2.607, foi criado o Banco de Desenvolvimento de Minas
Gerais, de natureza autárquica, cujo nome e espécie de ordem pública resultaram da supressão do vocábulo "agropecuário" e do S.A., que identifica sociedade anônima por ações. Enfim, fundou-se o Banco de Desenvolvimento de Minas Gerais (BDMG) em $5 / 2 / 1962$, sendo instalado com a posse de sua diretoria e dos membros do Conselho de Administração em 21/9/1962, nomeados por ato do governador Magalhães Pinto (Pereira-Diniz, 2008, p. 14-15, 17, 19 e 103). 
I Congresso Brasileiro de Desenvolvimento $\mathrm{Re}$ gional, em 1965, e contribuiu de forma decisiva para a elaboração do Diagnóstico. ${ }^{11}$ Assim, o BDMG mostrou-se fundamental para Minas Gerais, na medida em que alicerçou institucionalmente sua expansão econômica (Diniz, 2002).

Embora os projetos de desenvolvimento econômico em Minas Gerais nem sempre tenham seguido um mesmo rumo, e conquanto tenham sofrido algumas descontinuidades, parecem significativas a emergência e a consolidação, ao longo do período que se estende entre 1903 e 1968, da disposição ao planejamento econômico, baseado em crescente intervenção estatal e imposição de corpo técnico.

Sugere-se, portanto, que essa matriz desenvolvimentista de Minas Gerais imprescinde de corpo técnico que, significativamente, emerge e ganha complexidade no mesmo período. Conquanto a primeira instituição de formação técnica mineira, a Escola de Minas de Ouro Preto, date de 1876, somente a partir do princípio do século XX os engenheiros formados nesse estabelecimento começaram a alcançar maior projeção. Além disso, a fundação da Escola de Engenharia de Juiz de Fora, em 1914, e, em especial, a da Escola de Engenharia de Belo Horizonte, em 1911, são decisivas tanto para a compreensão da crescente complexidade da categoria profissional do engenheiro em Minas Gerais quanto para a análise do papel do corpo técnico regional na esfera pública, principalmente após 1933 (Barbosa, 2005). Do mesmo modo, o ensino agrícola superior, desta-

\begin{tabular}{|c|c|c|}
\hline $\begin{array}{l}\text { Técnicos do Departamento } \\
\text { de Estudos e Planejamento } \\
\text { do BDMG e colaboradores } \\
\text { da instituição participaram } \\
\text { ativamente do Congresso } \\
\text { promovido pelo governo } \\
\text { estadual, notadamente } \\
\text { pela apresentação de três } \\
\text { estudos, depois publicados } \\
\text { com o título Ensaios de } \\
\text { desenvolvimento regional. Entre } \\
\text { os nove autores dos textos, } \\
\text { dois não pertenciam aos } \\
\text { quadros do Banco e sete }\end{array}$ & $\begin{array}{l}\text { integraram, posteriormente, } \\
\text { o extenso grupo que } \\
\text { elaborou o Diagnóstico. Os } \\
\text { temas abordados versaram } \\
\text { sobre: i. o problema do } \\
\text { desenvolvimento regional } \\
\text { em perspectiva teórica; ii. } \\
\text { o caso de Minas Gerais; } \\
\text { iii. a proposição de marcos } \\
\text { para uma "política de } \\
\text { desenvolvimento regional } \\
\text { integrado". Considerados } \\
\text { em conjunto, os Ensaios } \\
\text { apresentam certa }\end{array}$ & $\begin{array}{l}\text { "organicidade" e definiram } \\
\text { premissas teóricas, estrutura } \\
\text { metodológica e pressupostos } \\
\text { analíticos que seriam } \\
\text { adotados, não exclusivamente, } \\
\text { na elaboração do Diagnóstico. } \\
\text { Nesses termos, nos Ensaios já } \\
\text { estão presentes a afirmação } \\
\text { e demonstração do "atraso } \\
\text { relativo" de Minas Gerais } \\
\text { no quadro do processo de } \\
\text { modernização econômica do } \\
\text { País, a tendência de crescente } \\
\text { "polarização do desenvolvimento }\end{array}$ \\
\hline
\end{tabular}

brasileiro" e seus reflexos na acentuação dos desequilíbrios regionais, os equívocos da visão prevalecente no "movimento regionalista no Brasil" e o imperativo em se considerar que a superação dos desníveis regionais somente será alcançada se entendida como "um problema de conteúdo político"

(Ensaios, 1965). 
12 Não deixa de ser sugestivo que os três coordenadores do Diagnóstico (Fernando Antônio Roquette Reis, Élcio Costa Couto e Álvaro Fortes Santiago) apresentassem estreito vínculo com a Face, sendo professor o primeiro, e os outros, egressos da instituição. cado como essencial quando do I CAIC, ganhará grande impulso com a fundação da Escola Superior de Agricultura e Veterinária, em 1926, na cidade mineira de Viçosa (Barbosa, 2004). Os engenheiros, formados no âmbito regional, em escolas reconhecidas nacionalmente, alcançam o Estado definitivamente após 1933 e, ainda que com dissidências internas à categoria, trabalham sistematicamente no entorno do poder público, ora em contato direto com a elite econômica regional (Vieira, 1984), ora a suplantando, organizando a defesa de seus interesses de forma bastante efetiva (Barbosa, 2005), valendo-se, na esfera da política, de argumentos essencialmente técnicos.

A esse fio condutor desenvolvimentista em Minas, portanto, pode ser somado o papel de elite técnica ativa, não apenas na esfera do poder público, mas também por meio de suas associações de categoria profissional (Barbosa, 2005). Nesse sentido, os engenheiros serão importantes desde 1903, especialmente nos períodos dos governos Valadares, Campos e Kubitschek. Conforme se salientou, também estarão presentes no BDMG e na formulação do Diagnóstico, muito embora contando, desde a década de 1940, com a presença da categoria profissional do economista, que começa a se forjar, em Minas, a partir da fundação da Faculdade de Ciências Econômicas e Administrativas (Face). A criação da Face e, principalmente, sua reformulação em 1945 (configurando a formação de bacharéis em Ciências Econômicas) são elementos capitais para a investigação que aqui se apresenta, por representar o início de expressiva inflexão intraelite técnica regional. ${ }^{12}$ Se é fato que o ensino das Ciências Econômicas é capítulo destacável no processo de modernização da economia brasileira, após 1930, também deve ser assinalada a relevância das condicionantes regionais no que tange à formulação de cursos de Economia, em especial em sua interação com os rumos das economias regionais e com seus grupos mais proeminentes (Paula, 2006).

A década de 1940 será significativa no campo do ensino de Economia no Brasil, na medida em que se assiste à emergência de vários cursos superiores, da mesma forma que se aprofunda o debate sobre os rumos da economia nacional. Enfatizando-se, então, a importante contenda entre Eugênio Gudin e Roberto Simonsen, nos âmbitos do Conselho de Planejamento Econômico e do Conselho Nacional de Política Industrial e Comercial, respectivamente (Motta, 
1994, p. 93). Além disso, elementos como a noção de planificação econômica, ganhando contornos com o Plano SALTE (na esfera federal) em 1947, e os desdobramentos da matriz da CEPAL, definindo como eixo de análise o conceito de subdesenvolvimento, trouxeram reflexos decisivos para o debate econômico e, por consequência, para o ensino de Economia. Desse modo, o período que se estende entre 1945 e 1964 demarcará, definitivamente, a ascensão da categoria profissional do economista em âmbito nacional, à proporção que se apresenta como o profissional de corte ideal para os desafios técnicos impostos pela realidade econômica. Segundo Motta (1994, p. 99),

a complexidade crescente da vida econômica exigia cálculos cada vez, mais sofisticados - renda nacional, balanco de pagamentos, indices de precos - e demandava profissionais especializados

Em síntese, considera-se que são quatro os elementos decisivos para a criação de espaços especificamente voltados ao planejamento em Minas Gerais:

i. a progressiva consolidação da categoria profissional do economista, a partir das primeiras turmas graduadas pela Face, cônscia dos problemas e dos limites do de- senvolvimento econômico mineiro;

ii. a matriz desenvolvimentista da CEPAL, notadamente a partir da década de 1950;

iii. a perspectiva do planejamento econômico que, conquanto tenha emergido no princípio do século XX, se estrutura com o Plano de Recuperação Econômica e Fomento da Produção, em 1947;

iv. a racionalização da administração pública, por meio da influência do estilo de gestão das empresas de capital misto mineiras. Entre esses espaços, por conseguinte, a criação do BDMG e sua preocupação com o planejamento da recuperação econômica e seu financiamento são fatores que, em linhas gerais, tendem a se refletir na produção do Diagnóstico.

\section{3_Dos diagnósticos}

Nesta seção são examinados estudos que compõem o Diagnóstico da Economia Mineira. Foram selecionadas quatro monografias específicas: transportes, energia elétrica, indústria açucareira e siderurgia. Transportes e energia elétrica possuem 
relação evidente, porque, conforme anteriormente apontado, representaram preocupação do poder público mineiro, de forma conjuntamente sistematizada, ao menos desde a proposição do Binômio Energia e Transportes, na primeira metade da década de 1950. Indústria açucareira e siderurgia representam, respectivamente, as faces tradicional e moderna do setor de transformação e são expressões de dois cursos distintos da economia do estado: as atividades agroaçucareiras sempre estiveram associadas ao mercado interno mineiro e são características de economia regional autônoma, ou pouco integrada à economia do restante do País; a siderurgia, conquanto em sua fase artesanal e manufatureira também seja originária de comum e secular processo de substituição de importações, desde o século XVIII e que alcançou máxima expressão na centúria seguinte, é exemplar de atividade que, em sua fase de grande indústria, se desenvolve articulada ao processo de integração do mercado interno nacional.

Uma das preocupações principais do Diagnóstico, em seu volume sobre a indústria, é a tentativa de se definir modelo que permita compreender o desenvolvimento mineiro. Não obstante a indústria regional estivesse em situ- ação de atraso relativo em comparação à paulista ou à guanabarina, buscou-se evidenciar a importância que o setor tivera, em Minas, desde os primórdios da colonização. Assim, como ao longo do documento, também no tocante à indústria procurou-se reconstruir sua história em Minas, evidenciando a relevância assumida nos mais diversos momentos da história regional.

É nesse sentido que, portanto, as considerações a respeito da recuperação econômica mineira no século XIX, póscrise da mineração, apontam para a importância da indústria têxtil e alimentícia, somada a uma tangencial importância da siderurgia mineira. É a observação em perspectiva histórica que permite, então, aos autores do Diagnóstico constituir quadro acerca da indústria mineira em que convivem dois setores: um setor tradicional e outro dinâmico. Nesse modelo, o setor tradicional corresponde às indústrias têxtil e alimentícia, emergentes no século XIX e que, em geral, apresentavam desconcentração geográfica, grande número de pequenas unidades, empregando poucos trabalhadores e com baixo nível tecnológico aplicado à produção. Em contrapartida, o setor dinâmico, que se constituiu entre o final do século XIX e início do século seguinte, do qual 
faziam parte a geração de eletricidade e a construção civil, e em que se destacava a siderurgia, apresentava-se em situação oposta: poucas e grandes unidades, concentração espacial e empresarial, tecnologia de ponta.

Portanto, no modelo proposto pelo Diagnóstico para a compreensão da indústria mineira, a estrutura é absolutamente dual (sendo esse, até mesmo, o termo empregado pelo documento para se referir a tal quadro): setor dinâmico e setor tradicional convivem lado a lado, ainda que correspondendo a duas realidades distintas. De um lado, a realidade de um estado pouco desenvolvido, com pequenos núcleos urbanos que fornecem a escassa e mal treinada mão de obra para plantas industriais modestas e obsoletas, dirigidas por empresariado impermeável à modernização. De outro lado, a realidade de uma Minas Gerais dinâmica, moderna, tecnologicamente avançada e pronta para emergir como grande centro produtor de ferro e aço.

Uma visão sintética da indústria na economia mineira no Século XIX evidenciaria a importância mínima do setor [siderúrgico] no contexto geral e sua ênfase nos ramos têxteis e de laticinios. Convém frisar que, já ai, se faz sentir a deficiente capacidade em- presarial do mineiro, variável de importância fundamental no processo de crescimento econômico e que parece constituir-se, até os dias atuais, num ponto de estrangulamento ao processo de desenvolvimento do Estado (Diagnóstico, 1968, v. V, p. 9).

O setor dinâmico tendia a não contar com esse empresariado, uma vez que se articulava com o apoio financeiro e operacional do poder público e do capital estrangeiro que, muitas vezes, por meio de empresas de capital misto, estavam a se associar e liderar o setor de eletricidade e de siderurgia, em larga medida responsáveis pelo incremento da indústria mineira no período coevo à elaboração do documento. Assim,

foi através desses segmentos dinâmicos de seu parque de indústrias que Minas se integrou no desenvolvimento brasileiro, na década dos 50 (Diagnóstico, 1968, v. V, p. 25).

Na leitura da realidade empreendida pelo Diagnóstico, o setor dinâmico da indústria mineira instalara-se nos moldes das economias avançadas, o que correspondia, então, à utilização maciça de tecnologia mesmo que em detrimento da grande quantidade de mão de obra não ocupada em Minas. Assim, de acordo com o documento, a prática de capital-intensi$v e$, que verticalizava a utilização de tec- 
13 "Critica-se, com relação aos métodos empregados neste grupo de indústrias [modernas], a inadequação dos processos produtivos à disponibilidade dos fatores.

Tecnologia 'capital-intensive' é criação de economias desenvolvidas, onde se verifica outra relação na disponibilidade dos fatores, caracterizada pela abundância relativa de capital e escassez relativa de mão-de-obra. Não é admissivel a transposição do sistema, em sua concepção original, para economias subdesenvolvidas, onde os fatores de produção guardam, entre si, relação diferente de disponibilidade. Poupar mão-de-obra quando ela é abundante, e usar intensamente o capital escasso bá de conduzir o sistema, em maior ou menor prazo, a situação de impasse" (Diagnóstico, 1968, v. V, p. 28). nologia em economias de mão de obra escassa, não correspondia às necessidades de uma economia tida por subdesenvolvida. ${ }^{13}$ Ou seja, era preciso que o setor dinâmico da economia mineira não apenas cumprisse seu papel de fomentador do avanço econômico regional, mas que, sobretudo, fosse articulado à necessidade premente de desenvolvimento que, de acordo com o Diagnóstico, não significava

desenvolver tão somente a indústria. Desenvolvimento é processo global de mudança social, com manifestações quantitativas (v.g. crescimento da renda per capita) e qualitativas (alterações nos quadros de poder e nos códigos de valores, por exemplo) (Diagnóstico, 1968, v. V, p. 29).

Nesse sentido, a indústria, e especialmente seu setor dinâmico, deveria ser compreendida como chave para o desenvolvimento regional, não obstante tivesse que, para isso, reformular sua atuação a ponto de atender às demandas sociais existentes, de modo que "cumpre, urgentemente, ajustar a técnica moderna à dotação relativa dos fatores, nas economias subdesenvolvidas. Ausente essa providência, há de se perpetuar, na estrutura industrial mineira, o modelo dual, incompatível com o desenvolvimento (Diagnóstico, 1968, v. V, p. 28).
Cabe, então, observar em que medida elementos específicos de ambos os setores (tradicional e dinâmico) foram analisados e interpretados, pelo Diagnóstico, quanto às suas respectivas funções ante o processo de desenvolvimento regional.

Os quatro casos aqui apresentados, conquanto sejam sobre temas evidentemente diversos, assemelham-se por alguns aspectos. Em primeiro lugar, pela capacidade de articulação entre o passado, o presente e o futuro de cada um dos estudos. Assim, ao diagnóstico do problema, observado em perspectiva histórica, seguia-se a avaliação do problema contemporâneo à feitura do Diagnóstico para, então, se estabelecerem os prognósticos. Em segundo lugar, pela percuciência na análise documental, bem como pela quantidade de dados e de fontes arrolados. E, por fim, pela situação de subdesenvolvimento de Minas Gerais, apontada pelos quatro estudos em questão, além da relação de dependência e de sujeição regional à dinâmica das economias vizinhas centrais (São Paulo e Guanabara).

A análise de cada uma dessas monografias cumpre a função, portanto, de tentar vislumbrar as principais características da produção do Diagnóstico, sua ca- 
pacidade investigativa e suas conclusões, mais que de averiguar a exatidão ou não das análises apresentadas.

\subsection{Transportes}

O diagnóstico dos transportes compõe o volume sobre a infraestrutura de Minas Gerais (Diagnóstico, 1968, v. III, p. 89-149) e representou estudo abrangente sobre o tema. Abordou todo o espaço estadual ou, como declarado na introdução, "a análise visa uma região-plano". O estudo contemplou o século XIX, estendeu-se até a data de produção do documento e, tematicamente, compreendeu todas as modalidades de transporte utilizadas com fins econômicos em Minas Gerais. O caráter essencial dos transportes no processo de desenvolvimento econômico foi demarcado já nas primeiras páginas do estudo. Justificou-se, portanto, o motivo de sua inclusão no Diagnóstico principalmente ao ressaltar-se que, para o bom funcionamento de uma economia, desse componente da infraestrutura não era possível prescindir. Nessa medida, afirmava-se que os transportes

ligam-se tão intimamente a uma economia, que merecem atenção especial, mesmo quando o processo de desenvolvimento não seja dinâmico, uma vez que uma involução será a conseqüência do estrangulamento da rede (Diagnóstico, 1968, v. III, p. 89).
No estudo são analisadas as ferrovias, as rodovias e a navegação fluvial, bem como os minerodutos, oleodutos e teleféricos; atributo que lhe confere caráter singular no rol dos trabalhos sobre os transportes mineiros que apresentam perspectiva histórica de abordagem, ${ }^{14}$ inclusive por utilizar não só bibliografia temática, mas também fontes primárias. ${ }^{15}$ Entre as modalidades contempladas, naturalmente ganharam maior atenção as ferrovias e as rodovias. Para ambas, foram dedicadas acuradas análises da história de sua implantação e também completo panorama das circunstâncias em que operavam quando da realização do trabalho. O estudo possui outra qualidade, constitui-se em leitura dinâmica do setor dos transportes, a possibilitar a percepção das relações entre a infraestrutura de transportes e a economia. Também, quando se vale do recurso sistemático da comparação com outras realidades - como a de São Paulo - e fornece parâmetros que alargam a compreensão do tema.

Sobressai do documento o reconhecimento da necessidade de se promover a efetiva integração econômica de Minas Gerais. Para se alcançar esse objetivo, a infraestrutura de transportes cumpriria função decisiva, ainda que de caráter instrumental. O diagnóstico dos trans-

\footnotetext{
${ }_{14}$ Excetuado o Diagnóstico, a única obra que fornece interpretação da história dos transportes mineiros, analisando-os em todas as suas modalidades, com recorte temporal largo e abrangendo todos os espaços de Minas Gerais, é o livro do engenheiro, ex-aluno da Escola de Minas de Ouro Preto, Demerval José Pimenta, Os caminhos de Minas Gerais, publicado em 1971 pela Imprensa Oficial de Minas Gerais.

15 Exemplos de fontes primárias utilizadas são: Anuários Estatísticos do Brasil, Revista Ferroviária, Dados do DER/MG, Revista do CNE, Planos de Viação (nacional e estadual). No corpo do texto e também em seus anexos, são oferecidos quadros com estatísticas importantes para o estudo dos transportes.
} 
${ }_{16}$ Parece consenso entre os estudiosos dos transportes a demarcação de fases ou eras correspondentes ao predomínio de uma modalidade de transporte. Assim, chamam de era rodoviária a que se inicia por volta da década de 1860 e se estende até o final da década de 1940, quando se iniciaria a era rodoviária. Para mais detalhes sobre essa discussão, ver Natal (1991). portes talvez possa ser resumido da seguinte forma: é necessário alterar, por meio de rodovias, o padrão de integração da economia estabelecido pela malha ferroviária. O retrospecto ressalta a origem das escolhas que orientaram a implantação da rede férrea mineira; a análise coeva evidencia, objetivamente, os frutos dessas escolhas, e ambos mostram a necessidade e a possibilidade de se evitar situações congêneres no futuro.

Assim, as ferrovias representavam o exemplo mais bem acabado daquilo que não deveria ser repetido. Elas exemplificavam infraestrutura cara e que, pela forma desordenada com que fora implantada, funcionava como obstáculo ao desenvolvimento econômico (Diagnóstico, 1968, v. III, p. 98). A rede ferroviária mineira, por meio de sua história e contemporaneidade, representava caso exemplar de infraestrutura estabelecida sem o menor planejamento, resultando na impossibilidade de cumprir a própria função para a qual foi criada: oferecer transporte mais eficiente.

No diagnóstico dos transportes, a história das ferrovias e das rodovias está entrelaçada. De tal modo que, mais que "eras" marcadas pelo predomínio de determinada modalidade, evidenciava-se, na descrição do processo de implantação da rede rodoviária mineira, o quanto essa fase era fortemente determinada pela anterior. ${ }^{16}$ As consequências da falta de planejamento durante o processo de formação da rede ferroviária mineira seriam, portanto, determinantes fundamentais quando do surgimento do "rodoviarismo". A implantação das rodovias estava fortemente condicionada pelas necessidades impostas pela ineficiência da modalidade ferroviária (Diagnóstico, 1968, v. III, p. 90).

O paradoxo da expansão ferroviária mineira foi enunciado já nas páginas introdutórias da análise, sendo apresentado por meio de excerto de obra de Pierre George, no qual se afirmava que a "intensidade do equipamento ferroviário regional é diretamente proporcional à do desenvolvimento da economia industrial da região", conceito que não se aplicava ao caso de Minas Gerais (Diagnóstico, 1968, v. III, p. 90). A incompatibilidade entre as ferrovias e o padrão de desenvolvimento econômico específico a Minas é bastante explorada, juntamente com os efeitos não integradores das ligações ferroviárias. A não integração das regiões mineiras resultaria, em grande parte, do padrão de articulação determinado pelas ferrovias. $\mathrm{O}$ estudo salienta realidade em que o parque industrial 
montado nas proximidades de Belo Horizonte não se integrava às economias das demais regiões do estado, no sentido de favorecer as trocas comerciais. Essas regiões - em que predominavam unidades produtoras de insumos - se integravam verticalmente com a economia de outros estados. Esse fato dificultava, por um lado, a constituição, na região central de Minas, de um verdadeiro complexo - ou polo - e, de outro, o desenvolvimento das outras regiões mineiras sob o influxo dos estímulos produzidos na primeira.

Nesses termos, as ferrovias responderiam, em parte, por esse padrão de integração que se queria superar, tendo em vista o sentido da penetração das vias férreas, quase sempre partindo dos complexos guanabarinos e paulistas e estabelecendo tradição de troca entre os centros regionais mineiros e aqueles polos. Assim, os centros urbano-industriais de Minas servidos por ferrovias não dinamizaram as suas relações comerciais recíprocas pelos seguintes motivos:

a. por suas estruturas semelhantes e concorrentes;

b. por não chegarem a constituir-se em núcleos de consumo razoáveis;

c. quase sempre preocupados em produção de bens exportáveis, funcionando como periferia de polos externos a que se encontravam vinculados (Diagnóstico, 1968, v. III, p. 91). A implicação dessa forma de integração foi a transformação desses centros urbano-industriais mineiros em várias unidades autônomas e independentes em relação aos centros vizinhos, cada qual se dissociando, em vários graus, da economia sub-regional e estadual.

Diante dessa realidade, as rodovias foram alçadas à posição de "alento da economia minera" (Diagnóstico, 1968, v. III, p. 101). Com a expansão e o melhoramento da rede rodoviária, objetivavase, portanto, mudar o padrão de integração. Assim, sugeriu-se um completo esquema de interligação regional de Minas com as rodovias do sistema nacional. Buscava-se, desse modo, integrar o mercado interno mineiro em novas bases e, consequentemente, mudar o padrão de integração econômica de Minas Gerais com os outros estados, principalmente com São Paulo e Rio de Janeiro. O potencial integrador das rodovias foi ponto marcante do estudo. Sugerem-se construções, prolongamentos e melhoramento de vias estaduais e federais (BRs e MGs). ${ }^{17}$ Quanto às ferrovias, constata-
${ }_{17}$ Após a descrição de programa de desenvolvimento da rede rodoviária, afirmouse que se impunha o prosseguimento da expansão visando à interligação das rodovias, nos seguintes termos: "Considere-se também que as ligações necessárias se estabelecem num sentido horizontal, verticais aos troncos rodoviários federais, invertendo-se completamente a orientação até aqui predominante de estradas longitudinais, cuja tendência era a de isolar, em relação ao Estado, as regiões a que serviam, dificultando a integração" (Diagnóstico, 1968, v. III, p. 119). 
18 O trabalho de Martins (1982) constituiu ponto de inflexão a determinar a superação das interpretações então prevalecentes antes da década de 1980, que consideravam a economia mineira do século XIX em situação de estagnação.

19 Como é possível depreender do excerto seguinte, que trata dos transportes em Minas Gerais, no século XIX, no qual se afirma que "não obstante a utilização desse precário meio de locomoção [muares], o fato é que a economia mineira prescindia de uma rede de transportes mais efica\%, ante a inexistência de produtos a serem transportados" (Diagnóstico, 1968, v. III, p. 96). va-se crescente ineficiência da rede, e a projeção era de desativação progressiva de ramais antieconômicos e não expansão da malha nos anos vindouros. Ressaltava-se também que as empresas e o governo federal tentavam recuperar e adequar as ferrovias ao tipo de transporte em que elas estavam se especializando: matérias-primas e cereais a granel - principalmente como incentivo à intensificação da mineração de ferro em Minas Gerais (Diagnóstico, 1968, v. III, p. 93).

No estudo estão presentes as referidas três perspectivas: histórica, diagnóstico e prognóstico. Contudo, a história da rede viária nacional somente é considerada a partir da modernização ferroviária, com exceção da única via de características técnicas consideradas aceitáveis, a União e Indústria (Diagnóstico, 1968, v. III, p. 97). Para os autores do Diagnóstico, a história dos transportes no Brasil começa com a Lei de Feijó, de 1835, não excluída Minas dessa linha de interpretação. Para o caso de Minas Gerais, soma-se a essa perspectiva certa compreensão histórica comum à época da realização do Diagnóstico, a noção de que a economia mineira do século XIX caracterizou-se por estagnação que se seguiu ao declínio das atividades de extração do ouro. ${ }^{18}$ Consequentemente, a modernização dos transportes ainda não se apresentava como imperativo, posto que os transportes tradicionais adequavamse a determinado padrão de economia. ${ }^{19}$

Em síntese, o estudo não só sistematiza os conhecimentos disponíveis sobre os transportes mineiros, mas também produz conhecimento com base em fontes primárias, consubstanciando-se em uma interpretação sobre a implantação da rede ferroviária e rodoviária mineira. Esse perfil mais informativo e interpretativo convive com a sua função de documento que orientaria políticas de intervenção na infraestrutura dos transportes.

\section{2_ Energia elétrica}

Consoante à perspectiva de se atribuir a Minas Gerais perfil socioeconômico subdesenvolvido, a abordagem acerca da energia elétrica no estado, realizada pelo Diagnóstico, caracterizou-se pela tentativa de se evidenciar o impasse do desenvolvimento econômico regional no âmbito da economia brasileira. Conquanto retratasse um encaminhamento relativamente positivo para a política de eletrificação estadual, o documento ressaltou sua fragilidade ante os desafios impostos a uma economia em situação periférica.

Dividida em seis partes, distribuídas ao longo de cinquenta e duas pági- 
nas, a monografia sobre energia elétrica, disposta no volume III, sobre População e Infraestrutura, procurou traçar um perfil do potencial energético e hidráulico mineiro comparado com o quadro nacional, ressaltando desde as características desse potencial até os predicados do consumo e da Política de Eletrificação encampada pelo governo estadual na década de $1950 .{ }^{20}$ Observa-se também a preocupação do documento em dispor, nesses seis subcapítulos, tanto uma perspectiva avaliativa do cenário coevo quanto a análise da questão em perspectiva histórica e das principais estratégias a serem encampadas futuramente.

A história da geração de energia elétrica em Minas Gerais pode ser dividida, segundo o Diagnóstico, em duas fases, sendo o ano de 1950 considerado como marco cronológico dessa divisão. Para o documento, até 1950 a geração de eletricidade em Minas carecia tanto de fôlego na produção (espalhada por 439 pequenas usinas, de uso público ou privado, gerando um total de $217.000 \mathrm{~kW}$ ) como na distribuição, representando um sistema considerado frágil e disperso (Diagnóstico, 1968, v. III, p. 174-5). A fragilidade do sistema pré-1950 contrastava com o desproporcional potencial de geração de energia elétrica de Minas Gerais, de tal sorte que $93 \%$ do território correspondia às áreas de drenagem das seis principais bacias hidrográficas do estado (Diagnóstico, 1968, v. III, p. 173) ${ }^{21}$ Além disso, o quadro demonstrava enorme entrave ao desenvolvimento industrial da região, uma vez que não se demonstrava apto para suprir de eletricidade em qualidade e quantidade as indústrias que desejassem se instalar em Minas Gerais. De acordo com o Diagnóstico, essa realidade pré-1950, somada ao problema que representava para o desenvolvimento econômico regional, impunha ao Estado a necessidade de se articular uma agenda baseada na intervenção direta do poder público no setor.

$\begin{array}{ll}\text { an As principais fontes utilizadas } & \text { de Minas Gerais, dados da } \\ \text { pela monografia foram: } & \text { Companhia Vale do Rio Doce } \\ \text { publicações do Ministério das } & \text { e da Estrada de Ferro Vitória } \\ \text { Minas e Energia, publicações } & \text { Minas, dados do Conselho } \\ \text { do Serviço de Estatística da } & \text { Nacional do Petróleo, relatórios } \\ \text { Produção de Minas Gerais, o } & \text { da Cemig, dados do Instituto de } \\ \text { Anuário Estatístico do Brasil } & \text { Açúcar e do Álcool, do EPEA } \\ \text { do IBGE, publicações do } & \text { e do Diagnóstico Preliminar do } \\ \text { Conselho Nacional de Águas e } & \text { Conselho Nacional do Petróleo. } \\ \text { Energia Elétrica e relatórios da } & { }^{21} \text { Bacia do Paranaíba, Bacia do } \\ \text { Cemig. No tocante ao Balanço } & \text { Rio Grande, Bacia do Rio Doce, } \\ \text { Energético de Minas, também } & \text { Bacia do Rio São Francisco } \\ \text { comparado com o quadro } & \text { (levantamento baseado em } \\ \text { nacional, as principais fontes } & \text { dados preliminares), Bacia do } \\ \text { foram o Anuário Estatístico } & \text { Jequitinhonha e Bacia do Rio } \\ \text { do Brasil do IBGE, ano } & \text { Paraíba (Diagnóstico, 1968, } \\ \begin{array}{l}\text { 1966, publicações do Serviço } \\ \text { de Estatística da Produção }\end{array} & \text { v. III, p. 173). }\end{array}$


Para o pleno aproveitamento do potencial de eletrificação do estado, e especialmente para a solução do problema infraestrutural que representava a questão, a partir de 1950 o governo de Minas Gerais organizou uma Política de Eletrificação que, ao cabo, se concretizou com a fundação das Centrais Elétricas de Minas Gerais S/A. (Cemig), empresa de capital misto, mas de controle acionário estadual, no ano de 1952 (Diagnóstico, 1968, v. III, p. 175)..$^{22}$ Segundo o Diagnóstico, a Cemig representou, nesse sentido, inflexão essencial no tocante à geração e à distribuição de energia elétrica no estado, na medida em que criou um sistema de integração, interconexão e coordenação do processo (Diagnóstico, 1968, v. III, p. 175-176).

Baseada numa política de expansão tanto da geração de eletricidade quanto das linhas de transmissão de energia, e essencialmente amparada por uma perspectiva de desenvolvimento da economia regional, a Cemig assumiu a responsabilidade de verticalização do setor, tornando-se, já em 1966, a principal geradora de energia do estado e o segundo maior produtor de eletricidade do País, no período. As várias páginas dedicadas à Cemig, seja na monografia sobre energia elétrica, seja na específica sobre ela,

\footnotetext{
22 O Diagnóstico publicou, no volume VI, Serviços e Setor Público, monografia específica sobre a Cemig. No que tange à história da eletrificação em Minas Gerais, o estudo repete boa parte dos argumentos apresentados na monografia que aqui se discute sobre energia elétrica, conquanto verticalize a abordagem técnica sobre a geração e a distribuição de energia elétrica pela empresa e seja mais específico, também tecnicamente, no que concerne às projeções futuras. Dois pontos devem ser ressaltados, entretanto. Em primeiro lugar, no estudo
}

específico sobre a Cemig há análise mais apurada acerca do Plano de Eletrificação, enviado pelo Poder Executivo ao Poder Legislativo em 31 de agosto de 1951. Sobressai ao observador, contudo, um aspecto: a ausência de qualquer referência ao Plano de Eletrificação do Governo Milton Campos, que é considerado, por alguns trabalhos posteriores (como o de Dulci, 1999), base importante para o referido Plano. Em segundo lugar, a ausência quase absoluta da questão do fornecimento de energia elétrica gerada pela Cemig aos estados vizinhos, aspecto central da monografia sobre energia elétrica. Chega a ser interessante observar, quanto a esse segundo ponto, que, nos quadros e mapas sobre distribuição de eletricidade gerada pela empresa, apresentados na monografia sobre a Cemig, praticamente se ignora a posição geográfica do consumidor final dessa energia. No mapa 6, por exemplo, apresentado à página 178, demonstra-se que, do consumo total de energia da Cemig, em 1966, 70,9\% foram de uso industrial. Se pensarmos com base na argumentação do estudo sobre energia elétrica, podemos considerar que esse consumo não ocorreu exclusivamente em Minas; antes, boa parte dele se deu em São Paulo ou na Guanabara. Isso, contudo, não é sequer citado pelo estudo, inexistindo um único gráfico ao menos que cruze esse percentual de consumo industrial com a destinação final da energia gerada e distribuída pela Cemig. 
revelavam, entretanto, certo incômodo quanto à empresa e, em especial, quanto aos próprios rumos da Política de Eletrificação que deu origem à companhia. Conquanto a Cemig tivesse dinamizado o setor de energia elétrica em Minas, 47\% de sua produção era exportada, em 1966, ou para São Paulo ou para o antigo estado da Guanabara (Diagnóstico, 1968, v. III, p. 149-50). Assim, diziam os autores, boa parte do esforço de eletrificação do estado, em vez de atender às necessidades do desenvolvimento econômico mineiro, atendia ao avanço das economias vizinhas mais desenvolvidas. ${ }^{23}$

Uma das principais preocupações do documento foi demonstrar o alto custo de se efetivar uma política de eletrificação nos moldes em que se estabeleceu a de Minas Gerais. Não apenas na construção de grandes usinas, como também na de linhas de transmissão, de subestações abaixadoras e elevadoras, e na própria estrutura de integração do sistema, boa parte do capital investido pelo Estado havia sido proveniente da Taxa de Recuperação Econômica. Para o Diagnóstico, durante boa parte dos primeiros quinze anos de funcionamento da Cemig, a legislação vigente sobre as inversões de capitais em empresas de energia elétrica havia afastado o investidor pri- vado, seja nacional, seja estrangeiro. Assim, na ausência de investimento privado, coube ao Estado arcar com a maior parte da empreitada. E era natural que o fosse, na medida em que a solução do problema elétrico era tida como vital, tanto como a eliminação de um nó primordial do cenário de subdesenvolvimento regional como uma maneira de se alcançar a urbanização das diversas regiões do estado. Nesse sentido, a energia elétrica era compreendida como serviço essencial de utilidade pública.

Segundo o Diagnóstico, todavia, havia um paradoxo na atuação da Cemig, que se explicava justamente por ser a empresa uma sociedade de capital mis-

$\begin{array}{ll}\text { interessante o fato de } & \text { maiores hidrelétricas mineiras - } \\ \text { que a monografia sobre } & \text { Furnas e Peixoto - destinam a } \\ \text { energia elétrica abra suas } & \text { quase totalidade de sua produção } \\ \text { considerações trazendo a } & \text { aqueles Estados, evitando que a } \\ \text { informação dessa venda } & \text { insuficiência no fornecimento se } \\ \text { de energia para os estados } & \text { torne ponto de estrangulamento } \\ \text { vizinhos. Assim, logo após o } & \text { ambas as unidades da Federação" } \\ \text { primeiro parágrafo do texto, } & \text { (Diagnóstico, 1968, v. III, } \\ \text { que apresenta a "posição } & \text { p. 149). Somente na sequência } \\ \text { privilegiada" de Minas no } & \text { é que a monografia abordará } \\ \text { cenário brasileiro, vem a } & \text { a produção e o consumo } \\ \text { informação de que o estado } & \text { mineiros, bem como seu } \\ \text { pôde, devido ao seu potencial, } & \text { histórico de geração de } \\ \text { atender a São Paulo e à } & \text { energia, sempre ressaltando } \\ \text { Guanabara, concluindo que } & \text { a carência de energia a } \\ \text { "assim, atualmente, duas das } & \text { estrangular a indústria regional. }\end{array}$


to. Como ela precisava remunerar seus investidores, sua preocupação havia passado a ser a de vender, indistintamente, a energia elétrica que gerava para o mercado consumidor mais apto a adquirila. Com isso, boa parte da energia gerada pela Cemig (47\%) não era distribuída em Minas, estando 51\% de sua estrutura voltada para o fornecimento de eletricidade para os estados vizinhos, enquanto algumas regiões mineiras, com potencial de industrialização, não conseguiam se desenvolver em razão da carência de eletricidade. Para os autores do documento, portanto, a infraestrutura elétrica em boa parte financiada pelo Estado, pensada como forma de equacionar um entrave ao desenvolvimento regional, estava mais era fomentando o desenvolvimento externo que propriamente cumprindo seu papel de agente propulsor da dinamização da economia de Minas.

Nesse sentido, ao longo das mais de cinquenta páginas em que se discutiu a questão da energia elétrica em Minas Gerais, das quais a maioria se dedicava ao nítido avanço do setor e à importância da Cemig nesse progresso, não deixava de aparecer, insistentemente, a conclusão de que não é a indústria que precede à oferta de eletricidade; ao contrário, é a oferta de eletricidade que pre- cede a indústria. Assim, sugeria-se uma inflexão profunda na política da empresa, conferindo

ao abastecimento interno a mesma dinâmica verificada para o setor destinado ao fornecimento dos mercados de outros estados. A CEMIG não deveria esperar a criação de mercados no estado para então estabelecer seu fornecimento, pois sua ação é que implicará na industrialização das regiões e a conseqüiente ampliação da demanda (Diagnóstico, 1968, v. III, p. 187).

Para o Diagnóstico, embora a efetivação do Plano de Eletrificação tivesse ampliado substancialmente a geração de eletricidade em Minas, chegando a uma potência instalada de 1.888 .000 kW em 1966 , a baixa utilização per capita de eletricidade no estado, além de ser fator revelador do subdesenvolvimento econômico e da lenta urbanização regional, indicava que, no tocante à distribuição de energia elétrica, o Plano ainda não havia chegado ao seu intento. A conclusão apresentada ao final, no item "Balanço Energético do Estado", de que a lenha ainda era o fator energético mais utilizado em Minas Gerais representava, no limite, que os investimentos futuros deveriam ser direcionados para a ampliação da distribuição de eletricidade, evitando a exportação do produto, de sorte que se atacas- 
se o subdesenvolvimento regional com o pleno fornecimento de eletricidade precedente à industrialização.

\section{3_Indústria açucareira}

Integrado ao volume $\mathrm{V}$ do Diagnóstico da Economia Mineira (1968, p. 285-323), o ensaio histórico e de conjuntura sobre a indústria açucareira dividiu-se em duas partes. A primeira contemplou a evolução do setor no Brasil, dos primórdios, no século XVI, até meados da década de 1960. A segunda parte destinou-se ao exame da evolução do espaço canavieiro de Minas Gerais, da implantação do cultivo e transformação da cana, no início do século XVIII até a conjuntura do lustro inicial da década de $1960 .^{24}$

As fontes de informação consultadas para realização do ensaio compreenderam obras gerais sobre a História Econômica do Brasil, compêndios especializados sobre a História do Açúcar no Brasil e em Minas Gerais, dados estatísticos recolhidos pelo Instituto do Açúcar e do Álcool e pelo Instituto Brasileiro de Geografia e Estatística, além de estudos técnicos do Departamento de Planejamento do BDMG.

O exame da indústria açucareira no Brasil subdividiu-se em dois tópicos. No primeiro foram evidenciados aspec- tos considerados centrais à trajetória de quatro séculos e meio de produção mercantil de açúcar no Brasil, sobretudo as determinantes fundamentais dos ciclos de expansão e retração do setor. A produção para o mercado interno apenas foi considerada a partir do início do século XX, quando, depois de longa trajetória de perda de expressão, o açúcar brasileiro tornou-se irrelevante no mercado internacional e se fortaleceram importantes conexões inter-regionais entre os antigos espaços canavieiros do Nordeste e os principais mercados consumidores do Centro-Sul.

Acompanhando linha cronológica, ao panorama dos quatro séculos de hegemonia da produção tradicional, seguiu-se análise do comportamento da indústria açucareira na primeira metade do século $\mathrm{XX}$, com acento nas assimétricas transformações do processo de modernização do setor, que projetou ao primeiro plano a agroindústria canavieira paulista. Para o período posterior a 1930, não se descurou de enfatizar a participação do Estado a desempenhar papel destacado, pela abrangente e, tantas vezes, decisiva regulação de todas as dimensões do setor.

O segundo tópico considerou a "evolução recente" ou a década e meia que antecedeu a realização e publicação do

\footnotetext{
${ }^{24}$ A síntese da evolução histórica do espaço canavieiro de Minas Gerais, do início do século XVIII até o final da centúria seguinte, baseou-se quase que exclusivamente na seminal obra de Miguel Costa Filho, A cana-de-açúcar em Minas Gerais (1963).
} 
Diagnóstico. Para o período 1950-65, foram ressaltados vários aspectos que expressariam as tendências contemporâneas da agroindústria açucareira do Brasil. Aos desequilíbrios regionais, manifestos na primeira metade do século XX, somaram-se movimentos conjunturais a sugerir quais seriam as inclinações futuras do setor. Foram expostos e discutidos dados pertinentes à produção, comércio, consumo, participação no mercado internacional, entre outros. Não apenas se tratou de realizar diagnóstico de conjuntura; também foram avançadas projeções relativas às prováveis configurações e inclinações do setor nas décadas futuras.

Do geral para o particular, a segunda parte do ensaio voltou-se para a apreciação do caso de Minas Gerais. Como referido, a agroindústria canavieira foi considerada em perspectiva histórica, desde os primórdios em território mineiro, na passagem do século XVII para o século seguinte, até a atualidade da elaboração do Diagnóstico.

Ainda que, de forma panorâmica, foram apreciados aspectos relevantes da trajetória da implantação e desenvolvimento do cultivo e transformação da cana nos séculos XVIII e XIX. Para o período colonial, assinalaram-se a estreita associação do desenvolvimento de ati- vidades agrícolas e o problema do abastecimento das populações especializadas na extração mineral, bem como a ambígua posição do Estado ante a expansão dos engenhos de cana, notadamente as reiteradas medidas que objetivaram obstar a expansão do número de unidades e da produção.

Com a emancipação política e o fim das restrições, ao período imperial foi associado grande desenvolvimento das atividades agroaçucareiras de Minas, que historicamente se orientavam para o mercado interno. Ressaltou-se que a pronunciada disseminação da produção no transcurso do Oitocentos projetou o estado, no início do século XX, à liderança nacional no cultivo da cana e no número de unidades produtivas com transformação da gramínea. Entretanto, buscou-se assinalar a relativa lentidão do processo de modernização da agroindústria canavieira de Minas, com a persistência da hegemonia da produção tradicional e uma série de problemas decorrentes.

Como na primeira parte, referente ao Brasil, no exame do caso de Minas Gerais conferiu-se destaque a "situação atual" da indústria açucareira, ou na década de 1950 e primeira metade do decênio seguinte. Foram apurados dados referentes à distribuição espacial dos en- 
genhos e das usinas, volume de produção, níveis de consumo, participação relativa do setor na economia do estado, entre outros. Despontou da análise desses dados a progressiva perda de importância relativa da agroindústria açucareira no setor industrial, em particular, e na economia do estado, em geral.

O decréscimo da expressão na economia regional foi entendido como consequência de características históricas do setor em Minas Gerais, notadamente o ritmo lento de modernização agrícola e industrial, a desconcentração espacial da produção a pulverizar os benefícios de economias de escala e de economias externas, a estrutura viária interna deficiente a onerar a circulação da produção, o impacto desfavorável da integração do mercado interno nacional a expor o setor à concorrência de espaços canavieiros mais dinâmicos e as políticas do Instituto do Açúcar e do Álcool que estimulavam a drenagem para Minas de excedentes regionais de espaços canavieiros mais dinâmicos.

Ao combinar a perspectiva histórica com a análise de conjuntura e ao considerar o tratamento regionalizado no quadro geral do País, o ensaio sobre a indústria açucareira de Minas Gerais apresentou-se sensível a múltiplas de- terminações interdependentes e logrou compreensão ampliada, habitualmente ausente de abordagens restritas ao tempo presente e a espaço particular. ${ }^{25}$ Independentemente das injunções políticas e ideológicas que presidiram as efetivas políticas públicas posteriores para o setor canavieiro, é assinalável que o ensaio sobre a agroindústria canavieira de Minas tenha reunido elementos fundamentais a permitir intervenção planejada com o objetivo de promover o desenvolvimento do setor. Foram salientados não apenas problemas estruturais e históricos, entendidos como obstáculos à modernização das atividades agroaçucareiras de Minas Gerais, mas até prognosticados os desdobramentos da realidade de estagnação, senão de decadência, em que se avaliava encontrar o setor. Também não faltaram indicações explícitas ou implícitas quanto à orientação que se preconizava para superar o quadro adverso diagnosticado. A natureza das eventuais intervenções que se seguiram à elaboração e publicação do Diagnóstico, os resultados alcançados e os principais beneficiários são problemas que ultrapassam os limites deste estudo.

\section{4_Siderurgia}

Presente no quinto volume do Diagnóstico da Economia Mineira, dedicado à In-

\footnotetext{
${ }_{25}$ Conquanto limitada pelo incipiente desenvolvimento da historiografia mineira no final da década de 1960 , a articulação de correta perspectiva histórica com abrangente análise de conjuntura e a necessária demarcação de aspectos particulares ao espaço canavieiro de Minas permitiram que a monografia sobre a indústria açucareira contemplasse processos de longo prazo como determinantes fundamentais do quadro de relativo atraso da modernização do setor (Godoy, 2004).
} 
${ }_{26}$ Os dados trabalhados pelo Diagnóstico foram predominantemente extraídos: do Diagnóstico da Siderurgia na América Latina e do documento Economia Siderúrgica Sul-Americana, ambos elaborados pela CEPAL; do Anuário Estatístico do Brasil, produzido pelo IBGE; do Instituto Latino Americano do Ferro e do Aço (ILAFA); do documento A Economia Siderúrgica na América Latina, em sua monografia específica sobre o Brasil, elaborado conjuntamente pela CEPAL, BID e IPES; do DEP do BDMG; do Instituto Brasileiro de Siderurgia (IBS); do Serviço de Estatística Econômica e Financeira do Ministério da Fazenda; da Companhia Vale do Rio Doce e da Companhia Siderúrgica Nacional. dústria, o estudo sobre a indústria extrativa mineral, especialmente no que tange à exploração do minério de ferro e à produção siderúrgica propriamente, representou ponto de inflexão entre os demais trabalhos que compõem o documento. Tendo em vista que o setor foi classificado como central ao setor dinâmico da economia regional, seu passado recente e perspectivas foram interpretados como positivos, estando, nesse sentido, menos vulnerável ao quadro do subdesenvolvimento que caracterizava a economia regional. No que concerne à sua apresentação, o modelo foi o mesmo das demais monografias, ressaltando-se a observação em perspectiva histórica do desenvolvimento do setor, o acompanhamento dos principais desdobramentos desse nas duas décadas imediatamente anteriores à publicação do Diagnóstico e, por fim, projetando movimentos futuros.

Metodologicamente, o estudo a respeito do minério de ferro, que precede a discussão concernente à metalurgia dos minerais ferrosos, na qual se insere a indústria siderúrgica, apresenta-se como as demais monografias do tópico intitulado Indústria Extrativa Mineral: expõe-se histórico, observação sobre a evolução recente do setor e análise acerca da situ- ação coeva - na qual cabem as projeções em relação ao futuro imediato do setor e amplo detalhamento no que concerne à localização geográfica das jazidas, acrescido de conjunto de dados sobre produção e os principais produtores, consumo interno e montantes exportados da produção e inferências sobre as reservas. Essa análise é apresentada tanto para o Brasil como especificamente para Minas Gerais, em capítulos distintos, até mesmo estabelecendo a relação entre os cenários brasileiro e mineiro - com destaque para a posição relativa de Minas no conjunto da produção da indústria extrativa mineral brasileira. ${ }^{26}$

Deve-se ressaltar, contudo, que, embora o modelo seja o mesmo, a riqueza no detalhamento da história da mineração de minério de ferro em Minas Gerais, na pormenorização do desenvolvimento siderúrgico regional e na pontuação de variadas disputas em torno do assunto ao longo da História, especialmente da questão siderúrgica (remontando a tentativa de Dom Rodrigo, ainda na Colônia, de instalação de uma fábrica de ferro na região de Minas Gerais, aos acordos firmados por Jean Monlevade na tentativa de implantação de fornos para a produção de ferro, à efetivação de estudos geológicos no Império 
ou mesmo ao detalhamento da instalação da Companhia Siderúrgica Nacional) torna sua parte histórica ainda mais relevante que em outros estudos publicados pelo documento.

Do mesmo modo, como referido, se certo tom pessimista configura os demais estudos, no caso da siderurgia essa perspectiva se inverte, recebendo o setor avaliação positiva. Assim, tanto o desempenho da extração de minério de ferro como o da produção siderúrgica ganham contornos otimistas, dada sua expressiva participação no desenvolvimento industrial mineiro desde, ao menos, 1921, com a fundação da Companhia Belgo-Mineira.

No que tange ao minério de ferro, de acordo com o Diagnóstico, "a história da mineração no Brasil é, praticamente, a história da mineração em Minas Gerais". E, sendo assim, não deixa de ser relevante perceber que, no encaminhamento dessa indústria, Minas Gerais apareça, sempre, como polo primordial na produção de minério de ferro no cenário brasileiro. O setor de extração de minério de ferro auferia, quando da produção do Diagnóstico, crescimento médio de $14,2 \%$ ao ano, possibilitando a expansão em larga escala da exportação do produto. Salienta-se que, de acordo com o do- cumento, $99 \%$ do minério produzido no Brasil era então oriundo de Minas Gerais, levando à conclusão de que o destacável crescimento produtivo e o surto exportador de minério de ferro eram fruto do bom desempenho de tal setor em Minas Gerais. Evidentemente, isso representava que o setor industrial mineiro acompanhava tal crescimento, uma vez que a produção e a exportação de minério de ferro correspondiam à parcela significativa do incremento do setor industrial em Minas Gerais (Diagnóstico, 1968, v. V, p. $48-49$ e 55).

Embora essencialmente positiva, a análise não deixou de demarcar, de forma bastante clara, a necessidade de se verticalizar a exploração do setor, para o qual o polo primordial era a Companhia Vale do Rio Doce (CVRD). Empresa de capital misto fundada em fins da Segunda Grande Guerra, a CVRD era a principal produtora (explorando as jazidas de Itabira) e responsável por quase a totalidade da exportação de minério de ferro brasileiro, sendo mesmo uma das mais importantes mineradoras do mundo em 1964. A Companhia era, portanto, a responsável pela exportação de sua produção e da das demais companhias instaladas no Quadrilátero Ferrífero, dividido entre o Vale do Rio Doce e o Vale do Rio 
Paraopeba. De acordo com o Diagnóstico, o principal problema enfrentado pela CVRD, e consequentemente pela economia regional nesse aspecto, era a falta de racionalização do processo de exploração das jazidas, que acarretava desperdício e baixa produtividade, resultado do baixo índice de mecanização da exploração. Segundo o documento, um terço das companhias exploradoras de minério de ferro no Vale do Paraopeba não adotava nenhum tipo de mecanização, ao passo que essa inexistia nas companhias exploradoras no Vale do Rio Doce (Diagnóstico, 1968, v. V, p. 55-57).

Se o problema da exploração do minério de ferro, portanto, configuravase como uma questão de mecanização, o mesmo não poderia ser assinalado em relação à produção siderúrgica propriamente dita, que, de acordo com o Diagnóstico, possuía tecnologia de ponta no Brasil, especialmente nas então recémfundadas Companhia Siderúrgica Paulista (Cosipa) e Usinas Siderúrgicas de Minas Gerais (Usiminas). Essa era, entretanto, a etapa final de um processo que, segundo o documento, se caracterizara, historicamente, por uma série de percalços a obliterar seu bom desempenho.

A siderurgia brasileira é compreendida pelos autores do Diagnóstico como atividade que remonta ao século XVI, quando as primeiras forjas foram instaladas em território brasileiro. Contudo, consideram que apenas a partir do século XX é que se constitui um parque siderúrgico nacional, cujo desenvolvimento pode ser periodizado em três fases distintas, segundo os tipos de usina implantados. A primeira fase começa com a inauguração, em Minas Gerais, da Companhia Belgo Mineira, em 1921, baseada na produção de ferro valendo-se de carvão vegetal. A segunda fase inicia-se com a instalação, em 1941, no Rio de Janeiro, da Companhia Siderúrgica Nacional, que, ao se estabelecer, utilizou-se do que havia de mais moderno em produção siderúrgica e, por decorrência, fez com que as indústrias se adequassem ao tipo de aço por ela produzido. A terceira fase principia com a instalação da Usiminas, em Minas, e da Cosipa, em São Paulo, já na década de 1960, que, mais modernas que a CSN, produziam aço de qualidade de exportação, mas que ainda enfrentavam mercado interno mais adaptado para os produtos da CSN. Deve-se ressaltar, portanto, que, embora o histórico sobre a siderurgia brasileira seja bastante completo e que, no geral, abarque mesmo os elementos mais longínquos, será a partir da instalação da Bel- 
go-Mineira que se configurará o núcleo da análise empreendida pelos autores da monografia sobre a siderurgia.

Enquanto Minas era responsável pela quase totalidade da extração e exportação do minério de ferro brasileiro, o título de principal produtor de ferro do País pertencia ao Rio de Janeiro desde o final da década de 1940, quando do início das operações da CSN, em Volta Redonda. Não obstante, desde a fundação da Belgo-Mineira, a siderurgia vinha desempenhando papel de relevo na economia regional, incrementando a participação de Minas no conjunto da produção industrial brasileira. Conquanto da criação da CSN tenha decorrido a perda da posição de principal produtora de ferro, inúmeras siderúrgicas de médio e pequeno portes continuaram a se instalar no estado, segundo o Diagnóstico, devido à proximidade com os fatores produtivos ofertados pela região - o que, de acordo com o documento, era um dos principais aspectos a explicar, até mesmo, a concentração espacial das siderúrgicas brasileiras na região Centro-Sul.

Nesse sentido, a indústria siderúrgica brasileira foi tratada de forma positiva e, em especial, a siderurgia mineira, que foi elevada ao posto de grande responsável pelo avanço do setor industrial do estado. De acordo com os dados apresentados pelo Diagnóstico, ao crescimento "animador" da siderurgia brasileira se sobrepunha a expansão da siderurgia mineira, que, ao crescer acima da média nacional, havia propiciado o aumento de sua participação no total da produção siderúrgica brasileira, incrementando também a participação da indústria mineira no total da produção industrial do $\mathrm{Pa}$ ís. Esse crescimento, mesmo que em pequenas e médias empresas (e que conduziu os autores do Diagnóstico a sugerirem a fundação de uma aciaria central que padronizasse o ferro e o aço produzidos em Minas), levou a compreensão de que era a siderurgia aquela que, enfim, elevaria o padrão industrial de Minas Gerais, possibilitando a suplantação do atraso relativo da economia regional. Para o documento, a siderurgia mineira já era fundamental no tocante à formação da renda interna e no emprego da mão de obra ligada à indústria regional.

Segundo o Diagnóstico, o aço se constituía em produto cujo índice de consumo - ao lado da energia elétrica determinava o grau de evolução e modernização de uma sociedade. Nessa perspectiva, o Brasil era apresentado como um país pouco desenvolvido, e por dois motivos. Em primeiro lugar, por ainda 
${ }^{27}$ Cabe notar que, segundo os autores do documento, por razões políticas, não explicitadas, a indústria automobilística brasileira ainda importava todo o aço que utilizava. utilizar mais ferro-gusa que aço, propriamente, e, em segundo lugar, por importar boa parte do pouco aço consumido ${ }^{27}$. Assim, coube aos autores do documento elaborar uma lista dos setores industriais que mais necessitavam de aço e, em especial, constando as estimativas de consumo futuro de cada setor.

Essa listagem, da forma em que se apresentou, discutindo ponto a ponto as necessidades de cada setor dependente do aço, representava, ao cabo, elemento vigoroso na argumentação apresentada pelo Diagnóstico no tocante ao desenvolvimento regional. Em linhas gerais, essa lista sugeria como principais setores dependentes do aço as indústrias de máquinas e implementos agrícolas (responsáveis pela dinamização agrícola), as de máquinas e equipamentos industriais (ligadas à racionalização produtiva da indústria de bens de consumo), as de máquinas e equipamentos para terraplenagem (fundamentais para o processo de urbanização em curso), as de equipamentos elétricos (essenciais para o avanço na produção e, especialmente, distribuição de energia), as de construção e reparos navais e a automobilística.

Os setores listados, portanto, tinham evidente relação com a dinamização da economia, seja por já perten- cerem ao setor dinâmico, seja por se ligarem ao tradicional - carente de dinamização. Tendo em vista a posição geográfica das jazidas de minério de ferro e a produção amplamente condicionada a Minas Gerais, o grande número de pequenas e médias unidades produtoras de ferro (carentes, apenas, de uma aciaria central), a posição geográfica central do estado mineiro, enfim, segundo o documento, dadas todas as características específicas de Minas, parecia muito provável que o estado se desenvolvesse enquanto grande parque industrial, na medida em que atrairia indústrias de bens de produção.

Desse modo, o Diagnóstico caracterizava a siderurgia como o possível eixo do desenvolvimento regional, uma vez que compreendia sua participação na economia mineira como muito positiva, dada sua grande capacidade de gerar empregos, aquecer o mercado e proporcionar grandes dividendos para os cofres públicos (Diagnóstico, 1968, v. V, p. 121).

Como ponta do setor dinâmico, a siderurgia mineira representava a possibilidade de suplantação do atraso relativo e, portanto, de equacionamento da situação de subdesenvolvimento que, no geral, caracterizava a economia regional 
de acordo com o Diagnóstico. Ao lado do predomínio quase absoluto de Minas Gerais na exploração do minério de ferro, consolidar participação privilegiada da siderurgia mineira no total nacional mais que determinar predomínio nesse setor implicava, portanto, inserir-se definitivamente como polo industrial de bens de produção, na medida em que o estado consolidava-se como eixo atraente justamente por conta de sua siderurgia avançada. Não obstante o subdesenvolvimento não esteja associado à produção siderúrgica regional, ele emerge tangencialmente como ponto a ser superado, por meio do redirecionamento dos investimentos no parque industrial brasileiro, de seu centro para a região periférica de Minas Gerais.

A monografia sobre a siderurgia é encerrada por um apanhado das principais siderúrgicas brasileiras do período. $\mathrm{Na}$ lista apresentada, a Companhia Siderúrgica Nacional desponta, em razão da grande quantidade de reservas de minério de ferro que controlava e o montante de sua produção, como a principal siderúrgica brasileira, mas seguida pela Usiminas e, com menor capacidade, pela Cosipa. Maior que a similar paulista, e com também majorado potencial futuro de produção, a Usiminas emerge como aposta de desenvolvimento da siderurgia mineira, especialmente pelo seu elevado grau de utilização de tecnologia - o que a torna destacável inclusive em relação a siderúrgicas tradicionais de Minas, como a Belgo-Mineira, a Acesita e a Mannesmann. Entretanto, se for considerada a necessidade de harmonização da tecnologia com o aproveitamento máximo da mão de obra abundante, apontamento ressaltado pelo Diagnóstico quando da análise acerca do setor dinâmico da indústria mineira, caberia ainda, mesmo que como tarefa do poder público, adequar a expansão do setor siderúrgico às necessidades de desenvolvimento do estado de Minas Gerais, que, conforme se discutiu anteriormente, transcende o mero crescimento industrial.

\section{4_Considerações finais}

Do exame de quatro estudos específicos do Diagnóstico da Economia Mineira, ressaltam alguns aspectos de grande relevância. Em primeiro lugar, a preocupação em conhecer, com o máximo de exatidão possível, a realidade de cada quadro investigado, seja em sua perspectiva histórica, seja em sua contemporaneidade. Em segundo lugar, o objetivo de demonstrar a pertinência do trabalho tecnicamente orientado no que tange à projeção de so- 
luções para os entraves diagnosticados, sem perder de vista que os problemas, se existiam, eram fruto tanto de escolhas malsucedidas quanto da própria dinâmica histórica que as precediam. E, em terceiro lugar, e de forma fundamental, por ressaltar o quadro de subdesenvolvimento prevalecente ou associado a cada setor da economia regional estudado, enquadrando-os na chave explicativa enunciada desde a primeira tese apresentada na introdução do Diagnóstico.

O sistema econômico-social de Minas Gerais apresenta tôdas as características de subdesenvolvimento, quer no seu aparelho produtivo como no seu quadro institucional. Os sintomas mais evidentes são o predominio da atividade agropecuária, a enorme diferença de produtividade entre o obreiro rural e o urbano, o baixo grau de urbanização e a prevalência de um código de valôres patrimonialista, e, pois, arcaico (Diagnóstico, 1968, v. I, p. 17).

Nesse sentido, a inadequação do desenvolvimento dos transportes resultante de insensibilidade diante das necessidades regionais, o considerado excessivo e prejudicial fornecimento de energia elétrica para estados vizinhos a repercutir negativamente no processo de industrialização de Minas, a lenta modernização das atividades agroaçucareiras que respondeu pe- lo forte declínio relativo da participação do estado na produção nacional e a expansão da indústria siderúrgica a reforçar a posição periférica de Minas Gerais ante os polos nacionais de São Paulo e Rio de Janeiro são exemplares, entre outros, dos sintomas apresentados por uma economia diagnosticada como "doente", relativamente atrasada e, por isso, subdesenvolvida.

Acredita-se que a compreensão do documento O Diagnóstico da Economia Mineira não pode prescindir da perspectiva histórica. Entende-se que não se pode esquecer que determinações econômicas, sociais, políticas e institucionais, de fundo conjuntural e, principalmente, histórico, combinaram-se para criar quadro favorável à maturação de certa interpretação, ou conjunto de interpretações, sobre o problema do subdesenvolvimento de Minas Gerais e de como superá-lo. Os próprios autores do Diagnóstico se percebiam agentes de transformação em curso e que urgia ganhar aceleração e profundidade, portanto partícipes privilegiados da própria História de Minas.

Conquanto não se possa negar que se trata de documento original pela abrangência temática, pela regular articulação de três níveis de abordagem (retrospectiva, conjuntural e prospectiva), 
pela inédita mobilização de expressivo corpo técnico, pela estreita associação da economia com outras disciplinas (Geografia, História, Sociologia, Política) e pela adoção de perspectiva metodológica a priorizar a sistemática comparação com outras realidades regionais e com o quadro nacional, ainda assim se assume que o Diagnóstico e seus autores são tributários de certa tradição de reflexão, concepção de projetos de desenvolvimento e efetiva intervenção na realidade regional, que remonta ao início do século XX.

É compreensível que a sedução da autoridade técnica, do discurso competente, notadamente em período de transição que resultaria na hegemonia de nova categoria profissional, inauguraria a "era dos economistas", tenha revestido o documento de alguma pretensão fundadora. Entretanto, impõe-se o reconhecimento de que premissas fundamentais à elaboração do Diagnóstico do final da década de 1960 já estavam presentes em documentos anteriores e sensibilizaram outros atores que pensaram e buscaram intervir na realidade econômica de Minas Gerais. Quais premissas? A consciência do atraso relativo, a matriz desenvolvimentista, o lugar do Estado, a importância do planejamento e o sub- desenvolvimento como problema a ser superado por meio de intervenção política. Quais documentos? Os relatórios do Congresso Agrícola, Industrial e Comercial de 1903, o parecer da Sociedade Mineira de Engenheiros de 1938 (Siderurgia Nacional e Exportação de Minério de Ferro), o Plano de Recuperação Econômica e Fomento da Produção de 1947 e o Plano de Eletrificação de Minas de 1950. Quais atores? João Pinheiro, Israel Pinheiro, Américo Renné Giannetti, Lucas Lopes, entre outros.

Ao sobrelevar a afinidade com elementos de longeva e também pioneira tradição, não se intenta ofuscar a importância do Diagnóstico. Ao contrário, sustenta-se a convicção de que a iniciativa da recém-criada autarquia, o Banco de Desenvolvimento de Minas Gerais, representou a culminância e, talvez esgotamento, da referida tradição. Enquanto auge, constituiu-se como a mais elaborada expressão do desenvolvimentismo mineiro, quiçá o estertor de certa modalidade de compreensão de nossos problemas econômicos. O estudo comparado ou cotejo do Diagnóstico de 1968 com as iniciativas do mesmo gênero posteriores, 1989 e 2002, provavelmente salientará mudança de paradigma, deverá acentuar a descontinuidade com a menciona- 
da tradição. Ruptura que deve encontrar explicação nas transformações no quadro nacional e regional, entre o início do Regime Militar, quando ainda se acalentavam projetos autênticos de desenvolvimento econômico combinado com desenvolvimento social, e as primeiras décadas da Nova República.

Por fim, augura-se que, transcorridos quarenta anos da publicação do primeiro grande documento produzido pelo BDMG, e no bojo da atual recrudescência da discussão política e econômica em torno do imperativo do desenvolvimento nacional, se possa suscitar ou renovar o interesse pelo estudo e pela reflexão que contemplem os ensaios setoriais e a síntese geral que compõem o Diagnóstico. Sem olvidar as limitações técnicas e teóricas que se pode imputar a documento produzido no final da década de 1960 , afirma-se que não é possível mais desconhecer a importância do Diagnóstico da Economia Mineira, e, por decorrência, urge incorporá-lo no quadro das mais importantes interpretações da formação histórica de Minas Gerais. 


\section{Referências bibliográficas}

BARBOSA, Lidiany Silva. Roupa nova para a velha senhora agrária: os engenheiros-agrônomos e a modernização do campo em Minas Gerais. 2004. Dissertação (Mestrado em Extensão Rural) DER/UFV, Viçosa, 2004.

BARBOSA, Daniel Henrique Diniz. Os técnicos em ação. Os engenheiros de Minas Gerais e as alternativas de desenvolvimento regional. (1935-1945). 2005. Dissertação (Mestrado em História) PPGH/FAFICH/ UFMG, Belo Horizonte, 2005.

BLUTEAU, Raphael. Vocabulário Português e Latino. Coimbra: Colégio das Artes da Companhia de Jesus e Patriarcal Oficina da Música, 1712-1728.

CALDAS AULETE, Francisco Júlio. Dicionário Contemporâneo da Lingua Portuguesa. 2. ed. Lisboa: Parceria Antônio Maria Pereira, 1925.

CANO, Wilson. Desequilíbrios regionais e concentração industrial no Brasil: 1930-1970. São Paulo: Global; Campinas: Editora da Unicamp, 1985.

\section{CONSTANCIO, Francisco}

Solano. Novo Dicionário Crítico e Etimológico da Língua Portuguesa. 5. ed. Paris: Angelo Francisco Carneiro Filho, 1854.
COSTA FILHO, Miguel. A canade-acúcar em Minas Gerais. Rio de Janeiro: Instituto do Açúcar e do Álcool, 1963.

DELGADO, Ignácio Godinho. Estado e associações empresariais em Minas: a estratégia de um revés. Juiz de Fora: UFJF, 1997.

DIAGNÓSTICO da Economia Mineira. Belo Horizonte: BDMG, $1968.6 \mathrm{v}$.

DIAS, Fernando Correia. Estado e desenvolvimento em Minas Gerais. Revista Brasileira de Estudos Políticos, Belo Horizonte, Imprensa Oficial da UFMG, n. 25-26, jan./jul. 1969.

DIAS, José Luciano; FERREIRA, José Pelúcio. Banco Nacional de Desenvolvimento Econômico e Social. In: Dicionário HistóricoBiográfico Brasileiro. v. 1. Rio de Janeiro: CPDOC/FGV, 2001.

DINIZ, Clélio Campolina. Estado e capital estrangeiro na industrialização mineira. Belo Horizonte: UFMGPROED, 1981.

DINIZ, Clélio Campolina. Economia e planejamento em Minas Gerais: notas para discussão. In: DULCI, Otávio; PAIVA, Paulo de Tarso Almeida (Org.). 20 anos do Seminário sobre a Economia Mineira 1982-2002: coletânea de trabalhos. Vol. 3. Belo Horizonte: UFMG/ Face/Cedeplar, 2002.
DULCI, Otávio Soares. Política e recuperação econômica em Minas Gerais. Belo Horizonte: Editora da UFMG, 1999.

DULCI, Otávio Soares. João Pinheiro e as origens do desenvolvimento mineiro. In: GOMES, Ângela de Castro. Minas e os fundamentos do Brasil moderno. Belo Horizonte: Editora da UFMG, 2005.

ENSAIOS de desenvolvimento regional. Belo Horizonte: BDMG, 1965.

FERREIRA, Aurélio Buarque de Holanda. Novo Dicionário da Lingua Portuguesa. 2. ed. Rio de Janeiro: Nova Fronteira, 1986.

FIGUEIREDO, Antônio Cândido de. Novo Dicionário da Língua Portuguesa. 5. ed. Lisboa e Rio de Janeiro: Livraria Bertrand e W. M. Jackson, 1936.

FISICHELA, Domenico. Tecnocracia. In: BOBBIO, Norberto; MATTEUCCI, Nicola; PASQUINO, Gianfranco. Dicionário de Política. 4. ed. v. 2. Brasília: Editora da UnB, 1992. FREIRE, Laudelino Oliveira. Grande e Novíssimo Dicionário da Lingua Portuguesa. Rio de Janeiro: Editora A Noite, 1939-1944.
GODOY, Marcelo Magalhães.

No país das minas de ouro a paisagem vertia engenhos de cana e casas de negócio - um estudo das atividades agroaçucareiras tradicionais mineiras, entre o Setecentos e o Novecentos, e do complexo mercantil da província de Minas Gerais. 2004. Tese (Doutorado em História) - PPGHE/FFLCH/ USP, São Paulo, 2004.

HOUAISS, Antônio. Dicionário Honaiss da Lingua Portuguesa. Rio de Janeiro: Objetiva, 2001.

LEMOS, Maximiano. Enciclopédia Portuguesa Ilustrada. Dicionário Universal. Porto: Lemos \& C. ${ }^{\text {, }}$ Sucessor, 1899-1908?

LESSA, Carlos. Quinze anos de política econômica. São Paulo: Unicamp-Brasiliense, 1975.

MARTINS, Roberto Borges. A economia escravista de Minas Gerais no século XIX. Belo Horizonte: Cedeplar/ UFMG, 1982. (Texto para discussão, 10).

MINAS GERAIS. Secretaria de Viação e Obras Públicas. Plano de Eletrificação de Minas Gerais. Belo Horizonte, 1950.5 v. 
MINAS GERAIS. Plano de Recuperação Econômica e Fomento da Produção. Edição Fac-similar Comemorativa dos 20 anos de Elaboração. Belo Horizonte, 1967.

\section{MINAS GERAIS. Congresso} Agrícola, Industrial e Comercial de 1903. Fundação João Pinheiro. v. 1, n. 5-6, p, 122-220, maio/jun. 1981. Belo Horizonte: Fundação João Pinheiro, 1981.

MOTTA, Marly Silva da.

Economistas: intelectuais, burocratas e 'mágicos'. In: Gomes, Ângela M. de Castro. (Org.). Engenheiros e economistas: novas elites burocráticas. Rio de Janeiro: FGV, 1994.

NATAL, Jorge Luiz Alves. Transporte, ocupação do espaço e desenvolvimento capitalista no Brasil: história e perspectivas. 1991. Tese (Doutorado em Economia) - Instituto de Economia da Unicamp, Campinas, 1991.

O CRUZEIRO. Depois do 'diagnóstico' o remédio: estamos trabalhando. Rio de Janeiro: 13/1/1970.

O DIÁRIO DE MINAS. Minas em diagnóstico. Editorial. Belo Horizonte: 5/1/1969, p. 5.

PAULA, João Antônio de. O ensino e a pesquisa em economia na Universidade Federal de Minas Gerais. In: Análise, v. 17, n. 2, p. 329-344, jul./dez. 2006. Porto Alegre: Face/PUCRS.
PEREIRA, Lígia Maria Leite; LE VEN, Michel Marie (Org.). Ciência, tecnologia e Estado: trajetória da Fundação Centro Tecnológico de Minas Gerais, Cetec 1972-2002. Belo Horizonte: Cetec, 2002.

PEREIRA-DINIZ, Hindemburgo Chateaubriand. BDMG, histórico e desafios. Belo Horizonte: BDMG, 2008.

PIMENTA, Demerval José. Os caminhos de Minas Gerais. Belo Horizonte: Imprensa Oficial, 1971.

SILVA, Antônio de Moraes. Dicionário da Lingua Portuguesa. 4. ed. Lisboa: Impressão Régia, 1831.

SÍNTESE do Diagnóstico da Economia Mineira. Belo Horizonte: BDMG, 1967.

TAVARES, Maria da Conceição. Da substituição de importações ao capitalismo financeiro. Rio de Janeiro: Zahar, 1973.

VIEIRA, Domingos. Grande Dicionário Português ou Tesouro da Lingua Portuguesa. Porto: E. Chardrom \& Bartholomeu H. de Moraes, 1871-1874.

VIEIRA, Evantina Pereira. Minas Gerais: a dominação burguesa conflitos políticos e formas de organização (1927-1940). 1984. Tese (Doutorado em História) USP, São Paulo, 1984.

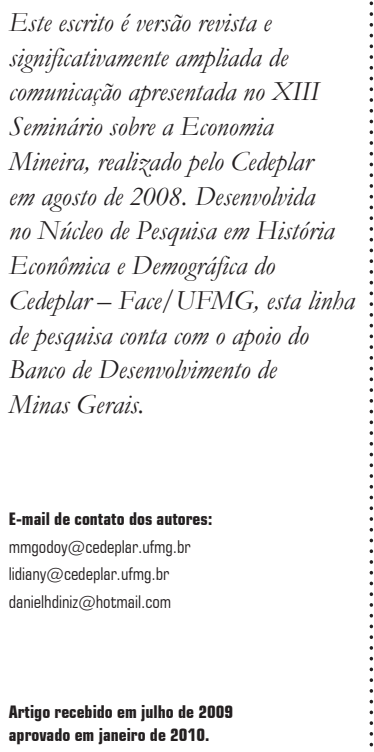


Anexo

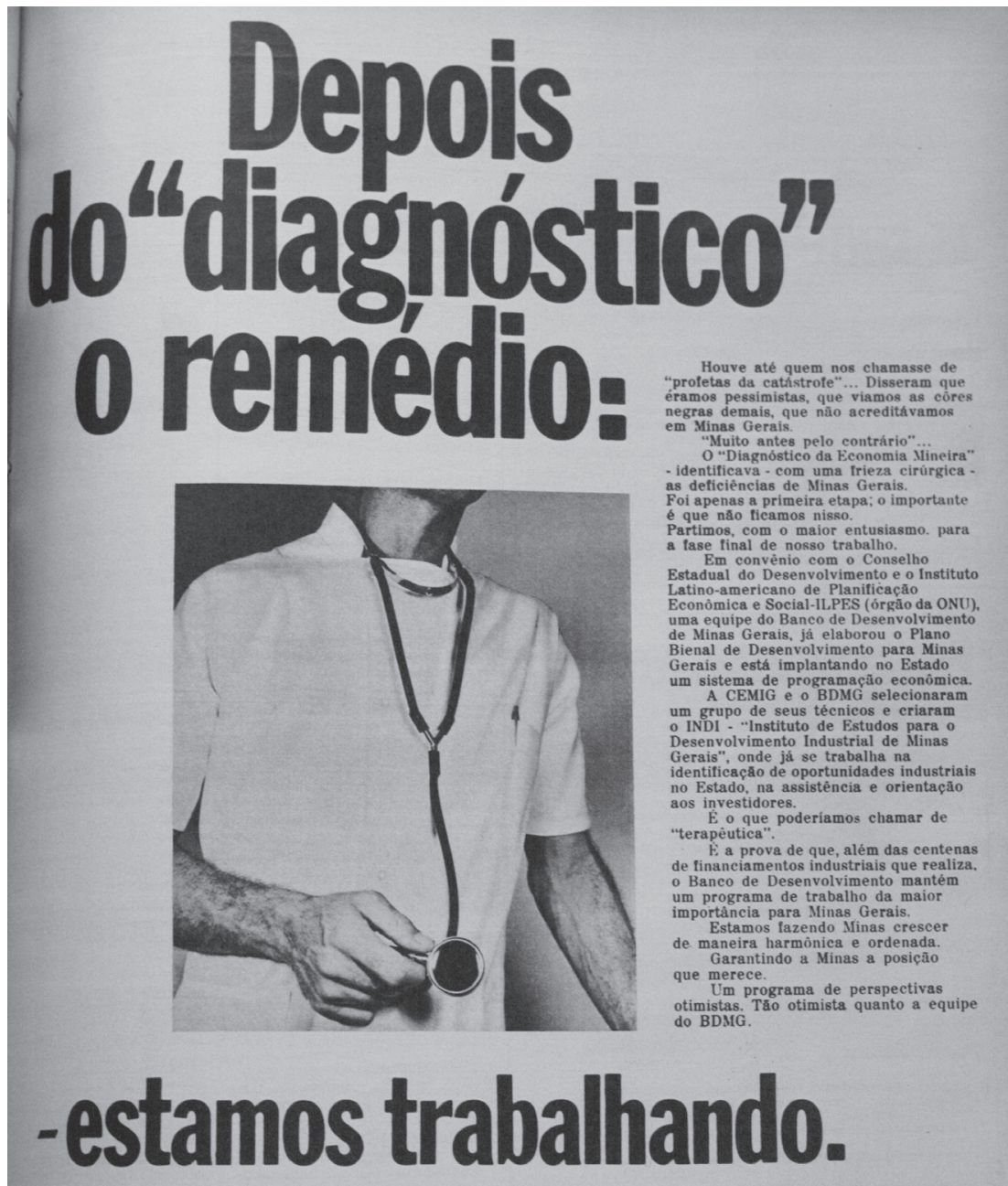

ASA

Banco de Desenvolvimento de Minas Gerais Govêrno do Estado de Minas Gerais 